\title{
PROGRESS RELATING TO CIVILIAN APPLICATIONS DURING OCTOBER, 1958
}

by

Russell W. Dayton

Clyde R. Tipton, Jr.

Chassification cancelled (or changed to

UNCLASSIFIED

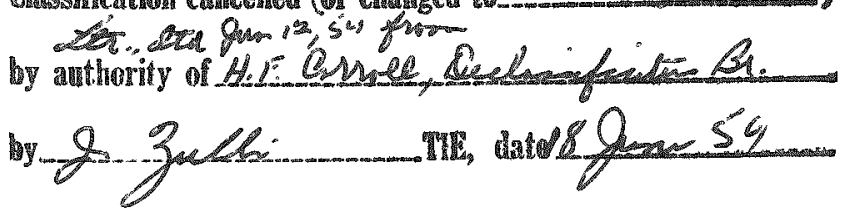

November 1, 1958

RESIFTCH-DA $A$

This domicher

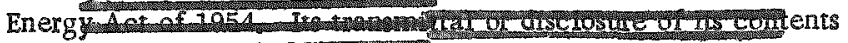

in any manner to an unathorized person is prohibited.

BATTELLE MEMORIAL INSTITUTE $505 \mathrm{King}$ Avenue

Columbus 1, Ohio 


\section{DISCLAIMER}

This report was prepared as an account of work sponsored by an agency of the United States Government. Neither the United States Government nor any agency Thereof, nor any of their employees, makes any warranty, express or implied, or assumes any legal liability or responsibility for the accuracy, completeness, or usefulness of any information, apparatus, product, or process disclosed, or represents that its use would not infringe privately owned rights. Reference herein to any specific commercial product, process, or service by trade name, trademark, manufacturer, or otherwise does not necessarily constitute or imply its endorsement, recommendation, or favoring by the United States Government or any agency thereof. The views and opinions of authors expressed herein do not necessarily state or reflect those of the United States Government or any agency thereof. 


\section{DISCLAIMER}

Portions of this document may be illegible in electronic image products. Images are produced from the best available original document. 


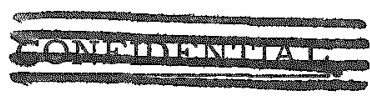

TABLE OF CONTENTS

Thermal Conductunty of Uranum and $\mathrm{UO}_{2} \cdot . . .$. .

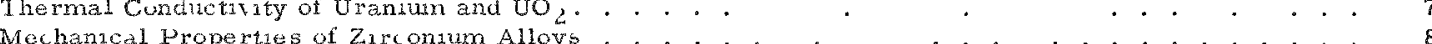

Physical Distortion of Graphite. . .

Prepartion of Mulybdenum Single Cxystals. . . . . . . . . . . . . . . . . . . . . . . 12

$\mathrm{B}$ DEVELOPMENTS FOR ALUMTNUM-CLAD FUEL ELLMENTS . . . . . . . . . . . . . . . . . . 13

Preparation of Alimizum-Uranum Alloys. . . . . . . . . . . . . . . . . . . . . . . . 13

Literature Survey for the Apprasal of Uranum Monocarbide as a Possible Nuclear Fuel. . . . . 14

C. RADIOISOTOPE AND RADIATION APPLICAIIONS . . . . . . . . . . . . . . . . . . . . 15

Development of Radroctuve-I racer Quality-Control System. . . . . . . . . . . . . . . . . 15

Radiation Chemistry of Inclusion Compounds. . . . . . . . . . . . . . . . . . . . . . . . . . . . 16

D PROCESSLIG OF FEED MAIERLALS . . . . . . . . . . . . . . . . . . . . . . . . . . . . 19

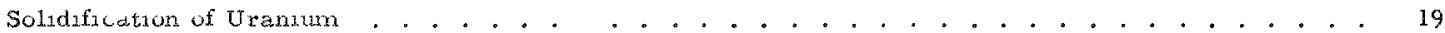

E. DEVELOPMENTS FOR LMFRE. . . . . . . . . . . . . . . . . . . . . . . . . . . . . 21

F RESEARCH FOR AEC REACTOR DEVELOPMENT DIVISION PROGRAM. . . . . . . . . . . . . . . 23

REACTOR MATERIALS AND COMPONENTS . . . . . . . . . . . . . . . . . . . . . . . 23

Valence Effects of Oride Additions to Urinium Dioxide . . . . . . . . . . . . . . . . . . . . . 23

High-Pressure High-Tempe rature Solid-State Studies . . . . . . . . . . . . . . . . . . . . 24

Fueled Zirconum Hydrode Moderator . . . . . . . . . . . . . . . . . . . . . . . . . . . . . . 25

Ir ladiation Survellance Program on Type 347 Stanless Steel . . . . . . . . . . . . . . . . . 26

STUDIES OF ALLOX FUELS . . . . . . . . . . . . . . . . . . . . . . . . . . . 27

Development of Niobrum-Uranum Alloys . . . . . . . . . . . . . . . . . . . . . . . 27

Development of Thorium-Uranam Alloys . . . . . . . . . . . . . . . . . . . . . . 28

GENERAL FUEL-ELEMENT DEVELOPMENT . . . . . . . . . . . . . . . . . . . . . 29

Eabrication of Cermet Fuel Elements. . . . . . . . . . . . . . . . . . . . . . . . . . . 24

Gas-Pressuxe Bondug of Molybdenum - and Niobium-Clad Fuel Elements . . . . . . . . . . . 30

Basx Studues of Pressure Bondung . . . . . . . . . . . . . . . . . . . . . . . . . . . 31

Factots Affecting Pressure Bonding . . . . . . . . . . . . . . . . . . . . . . . . . . . . . . . 32

C

FATIGUE STUDIES OF INCONEL AND INOR-8.................................. . . . . . . . . . .

Fatrgue Studies of Inconel . . . . . . . . . . . . . . . . . . . . . . . . . . 35

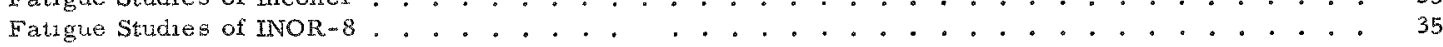

$\mathrm{H}$

PHYSICAL RESEARCH ... . . . . . . . . . . . . . . . . . . . . . . . . . . 37

Niolum -Gas Reactions ...................................37

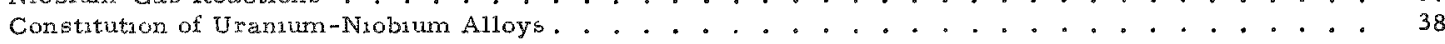

I SOLID HOMOGENEOUS EUELED REACTORS. . . . . . . . . . . . . . . . . . . . . . . . . . . . 39

Fabrication and Pre-Exposure Evaluation . . . . . . . . . . . . . . . . . . . . 39

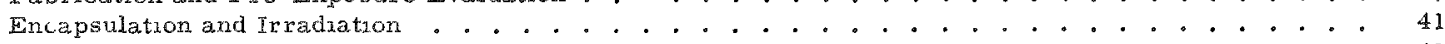

Postirradiation Examination . . . . . . . . . . . . . . . . . . . . . . . . . . 41 


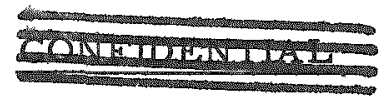

4

TABLE OF CONTENTS

(Continued)

J. CORROSION PROBLEMS ASSOCIATED WITH THE RECOVERY OF SPENT REACTOR

FUEL ELEMENTS . . . . . . . . . . . . . . . . . . . . . . 433

The Darex Process. . . . . . . . . . . . . . . . . . . . . . 43

The Sulfex-Thorex Process . . . . . . . . . . . . . . . . . . . . 44 4

The Fluoride-Volatility Process . . . . . . . . . . . . . . . . . . . . . 4 46

K. DEVELOPMENTS FOR SRE, OMRE, AND OMR . . . . . . . . . . . . . . . . . . . . 4 4

EVALUATION OF URANIUM MONOCARBIDE AS A REACTOR FUEL . . . . . . . . . . . . . 47

Room-Temperature Elastac Modulus and Compressive Strength of Uranum Monocarbide . . . . 47

Irradiation of Uranium Monocarbide . . . . . . . . . . . . . . . . . . . 48 4

Postirradiation Examination of Uranum Monocarbide . . . . . . . . . . . . . . . . . . . . 48

Fission-Product Release From Irradiated Uranum Monocarbide . . . . . . . . . . . . . . 49

POSTIRRADIATION STUDIES OF SRE, OMRE, AND OMR FUEL MATERIALS . . . . . . . . . . 50

SRE Fuel Material ................................ 51

OMRE Fuel Elements . . . . . . . . . . . . . . . . . . . . . 52

OMR Fuel and Structural Materials. . . . . . . . . . . . . . . . . . . . 52

L. TANTALUM AND TANTALUM-ALLOY STUDLES . . . . . . . . . . . . . . 53

Development of Contaner Materials for LAMPRE Applications . . . . . . . . . . . . 53

Irradiation Damage of Tantalum . . . . . . . . . . . . . . . . . . 53

M. DEVELOPMENTAL STUDIES FOR THE PWR . . . . . . . . . . . . . . . . 55

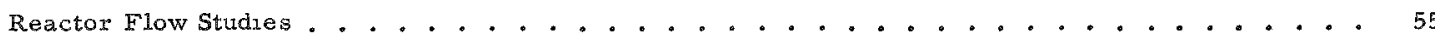

Pressure Bonding of Zircaloy-2-Clad Fuel Elements Containing Compartmented Oxade

Fuel Plates. . . . . . . . . . . . . . . . . . . . 55

N. DEVELOPMENTS FOR THE MGCR . . . . . . . . . . . . . . . . . . . . . 59

Investrgation of the Effect of Irradiation on Clad Graphite Specimens in a $\mathrm{CO}_{2}$ Environment. . . . 59 


\section{5 and 6}

REPORTS RELATING TO CIVILIAN APPLICATIONS ISSUED DURING OCTOBER, 1958

BMI-1290 "An In-Pile Gas-Cooled Loop Installed at the Battelle Research Reactor", by George F. Bodnar, Wallace J. Stevens, Gerald A. Francis, Sherwood I. Fawcett, and Albert M. Rockwood.

BMI-1292 "Design Features of Capsules for High-Temperature Irradiations", by John H. Stang, William H. Goldthwaite, and Bruce W. Dunnington.

BMI-1294 "Progress Relating to Civilian Applications During September, 1958", by Russell W. Dayton and Clyde R. Tipton, Jr. 
A-1

A. DEVELOPMENTS FOR ZIRCONIUM-CLAD FUEL EI_EMENTS

F. R. Shober

The thermal-conductivity and electrical-resistivity measurements of uranium encapsulated in Zircaloy-2 and surrounded with $\mathrm{NaK}$ as a heat-transfer material are not in agreement with results obtained from unclad uranium. It has been decided that the study on the effect of irradiation on these physical properties of uranium will be made with unclad uranium. Thermal-conductivity measurements of $\mathrm{UO}_{2}$ in the unirradiated condition indicate that there are only small differences in values for materials of between 85 and 95 per cent of theoretical density. The evaluation of creep and stress properties has continued on 15 per cent cold-worked Zircaloy-2 in the 290 to $400 \mathrm{C}$ temperature range. Some tests have been in progress as long as $9000 \mathrm{hr}$.

Preliminary experimentation on a sink-float method to separate graphite of various densities indicates that it may be possible to separate highly crystalline particles of nearly theoretical density and extremely-low-density particles that consist largely of disordered carbon. If so, the materials of the two densities could be irradiated separately, and effects of irradiation on each could be evaluated. Two additional molybdenum single crystals have been grown utilizing a steep temperature gradient in an Andrade type of furnace. Twelve single crystals are to be grown.

Thermal Conductivity of Uranium and $\mathrm{UO}_{2}$

C. F. Lucks and H.W. Deem

Uranium

During the past month thermal-conductivity and electrical-resistivity measurements were repeated on Specimen $J-K$. This specimen is uranium $-1.5 \mathrm{w} / 0$ zirconium, encapsulated in Zircaloy-2 with a NaK thermal "bond". The data checked with the results reported in BMI-1294 and were in disagreement with data for unclad uranium$1.5 \mathrm{w} / \mathrm{o}$ zirconium.

It has been decided that work on the encapsulated specimen will be discontinued and an attempt will be made to measure the thermal conductivity and electrical resistivity of bare uranium. These measurements will be made on unirradiated and irradiated samples.

\section{Uranium Oxide}

An apparatus for making thermal-conductivity measurements on $\mathrm{UO}_{2}$, both before and after irradiation, has been completed. A steady-state absolute method is being 
$A-2$

used. Briefly, accurately measured power is introduced into the top part of the specimen and the heat flows through the specimen into a heat sink. Compensated thermocouples at known positions measure the thermal gradients. The thermal conductivity of the specimen will be calculated from the heat flow, cross-sectional area, and the thermal gradients. Guarding to prevent stray heat flows has been provided.

Thermal-conductivity measurements have been completed on Specimen 65. Table A-1 gives interpolated thermal-conductivity values at selected temperatures. The interpolated values were read from a best curve drawn through 22 experimental points.

Next month, work will continue on $\mathrm{UO}_{2}$ measurements.

TABLE A 1 . INT ERPOLATED THERMAL CONDUCTIVITY OF UO 2 SPECIMEN 65 AT SELECTED TEMPERATURES

Specimen density: 87.4 per cent of theoretical.

\begin{tabular}{cc}
\hline $\begin{array}{c}\text { Temperature, } \\
\mathrm{C}\end{array}$ & $\begin{array}{c}\text { Thermal Conductivity, } \\
\mathrm{w} /(\mathrm{cm})(\mathrm{C})\end{array}$ \\
\hline 100 & 0.069 \\
200 & 0.056 \\
300 & 0.047 \\
400 & 0.040 \\
500 & 0.035 \\
600 & 0.032 \\
700 & 0.031 \\
800 & 0.030 \\
\hline
\end{tabular}

Mechanical Properties of Zirconium Alloys

F. R. Shober and J. A. VanEcho

The stress-rupture and creep properties of 15 per cent cold-worked Zircaloy-2 are being investigated in the 290 to $400 \mathrm{C}$ temperature range in vacuum. Stress levels have been chosen such that the creep tests fall into three categories with respect to rupture times; short times, 1 to $1000 \mathrm{hr}$; long times, 100 to $5000 \mathrm{hr}$; and rupture in times greater than $10,000 \mathrm{hr}$. The time for the initiation of third-stage creep and the total deformation as sociated with it are of interest. Retention of the increased strength during creep at elevated temperatures achieved by cold working prior to testing is also being investigated.

The twelve creep units currently in use contain specimens loaded at stresses that very probably will continue for times greater than 10,000 hr before failure. These specimens have been on test for approximately $9000 \mathrm{hr}$. Total deformations have not exceeded 1.0 per cent and creep rates are less than 0.00001 per cent per hr for the long-time tests. 
A-3

Future work will include an investigation of the effect of a cyclic temperature (room to an elevated temperature) on the creep properties of the 15 per cent coldworked material at 290 and $345 \mathrm{C}$. The times at room temperature and elevated temperatures have been selected to represent expected service conditions for the material. It is also planned to test additional annealed Zircaloy-2 at 290 and $345 \mathrm{C}$ for further comparison with the cold-worked material.

\section{Physical Distortion of Graphite}

J. Koretzky, W. C. Riley, and W. H. Duckworth

Research to develop a method of sink-float measurement to identify factors affecting irradiation-induced volume changes in graphite was continued.

A bar sample of TS-GBF was crushed and separated into nine particle-size ranges varying from minus 40 plus 60 to minus 325 -mesh. The following procedure was used to measure the density distribution of particles in a given size range: A sample of about $0.5 \mathrm{~g}$ was outgassed at room temperature for $30 \mathrm{~min}$. The sample was flooded with benzene to minimize reocclusion of gases on the surface and transferred to a centrifuge tube. About $75 \mathrm{ml}$ of a benzene-bromoform solution of low specific gravity was added. The sample was centrifuged for $5 \mathrm{~min}$ and allowed to come to rest. The light fraction and the benzene-bromoform were drawn of $f$ by suction. A fritted glass filter separated the graphite from the benzene-bromoform solution. The specific gravity of the filtrate was measured. The filter cake was washed with acetone, dried, and weighed. A solution of benzene-bromoform of a higher specific gravity was added to the heavy fraction and the mixture centrifuged. The above procedure was repeated with liquids of successively higher specific gravity until all material floated. The weight per cent floated on each liquid of known specific gravity was calculated. The results obtained to date are summarized in Tables $A-2, A-3$, and A-4.

The centrifuge method may allow the separation of highly crystalline particles of nearly theoretical density and extremely-low-density particles that consist largely of disordered carbon. These two fractions could be irradiated separately, and the effects of radiation on highly crystalline graphite and disordered carbon may be studied individually. A sample of minus 270 plus 320 -mesh graphite, which was floated by a solution of 1.835 specific gravity, was sent to another site for $\mathrm{X}$-ray analysis.

The density distribution of the other size ranges will be determined. Several size ranges will be combined to determine the value of close sizing graphite particles. The results will be compared with the density distribution of powder from another crushedbar sample to determine the variance from bar to bax. 
TABLE A-2. DENSITY DISTRIBUTION OF MINUS 40 PLUS $60-M E S H$ GRAPHITE

\begin{tabular}{|c|c|c|c|}
\hline $\begin{array}{c}\text { Specific Gravity of Benzene- } \\
\text { Bronoform Solution }\end{array}$ & $\begin{array}{c}\text { Amount Floated, } \\
\mathrm{g}\end{array}$ & $\begin{array}{l}\text { Amount Floated, } \\
\text { w/o }\end{array}$ & $\begin{array}{l}\text { Cumulative Amount } \\
\text { Floated, w/o }\end{array}$ \\
\hline 1.282 & $\infty$ & - & $-\infty$ \\
\hline 1.302 & $-\infty$ & $\ldots$ & $-\infty$ \\
\hline 1.362 & $\cdots$ & - & $\infty$ \\
\hline 1.480 & 0.0002 & 0.04 & 0.04 \\
\hline 1.580 & 0.0001 & 0.02 & 0.06 \\
\hline 1.580 & 0.0002 & 0.04 & 0.10 \\
\hline 1.632 & 0.0004 & 0.06 & 0.16 \\
\hline 1.709 & -- & -- & 0.16 \\
\hline 1.729 & 0.0007 & 0.14 & 0.30 \\
\hline 1.802 & 0.0005 & 0.10 & 0.40 \\
\hline 1.850 & 0.0004 & 0.06 & 0.46 \\
\hline 1.898 & 0.0005 & 0.10 & 0.56 \\
\hline 1.905 & 0.0020 & 0.40 & 0.36 \\
\hline 2.060 & 0.0136 & 5.25 & 6.21 \\
\hline 2.072 & 0.0068 & 2.03 & 8.24 \\
\hline 2.149 & 0.3011 & 60.88 & 69.12 \\
\hline 2.205 & 0.1504 & 30.48 & 99.60 \\
\hline 2. 229 & 0.0010 & 0.28 & 99.82 \\
\hline 2.267 & 0.0009 & 0.18 & 100.00 \\
\hline
\end{tabular}




$$
\text { A-5 }
$$

TABLE A-3. DENSITY DISTRIBUTION OF MINUS 100 PLUS 140 MESH GRAPHITE

\begin{tabular}{cccc}
\hline $\begin{array}{c}\text { Specific Gravity of Benzene- } \\
\text { Bromoform Solution }\end{array}$ & $\begin{array}{c}\text { Amount Floated, } \\
g\end{array}$ & $\begin{array}{c}\text { Amount Floated, } \\
\text { W/o }\end{array}$ & $\begin{array}{c}\text { Cumulative Amount } \\
\text { Floated, W/o }\end{array}$ \\
\hline 1.608 & 0.0006 & 0.12 & 0.12 \\
1.719 & 0.0003 & 0.06 & 0.18 \\
1.907 & 0.0028 & 0.56 & 0.74 \\
2.031 & 0.0016 & 0.32 & 1.06 \\
2.081 & 0.0240 & 4.83 & 5.89 \\
2.174 & 0.2422 & 48.79 & 54.68 \\
2.216 & 0.2181 & 43.93 & 98.61 \\
2.253 & 0.0069 & 1.39 & 100.00 \\
\hline
\end{tabular}

TABLE A-4. DENSITY DISTRIBUTION OF MINUS 270 PLUS 325-MESH GRAPHITE

\begin{tabular}{cccc}
\hline $\begin{array}{c}\text { Specific Graviry of Benzene- } \\
\text { Bromoform Solution }\end{array}$ & $\begin{array}{c}\text { Amount Floated } \\
\text { g }\end{array}$ & $\begin{array}{c}\text { Amount Floated } \\
\text { W/o }\end{array}$ & $\begin{array}{c}\text { Cumulative Amount } \\
\text { Floated, w/o }\end{array}$ \\
\hline 1.424 & 0.0027 & 0.55 & 0.55 \\
1.589 & 0.0076 & 1.54 & 2.09 \\
1.835 & 0.0085 & 1.72 & 3.81 \\
2.029 & 0.0013 & 0.26 & 4.07 \\
2.090 & 0.0940 & 19.05 & 23.12 \\
2.110 & 0.1179 & 23.83 & 46.95 \\
2.202 & 0.2101 & 42.47 & 89.42 \\
2.226 & 0.0566 & 10.55 & 99.97 \\
2.235 & 0.0002 & 0.03 & 100.00 \\
\hline
\end{tabular}


Preparation of Molybdenum Single Crystals

J. A. DeMastry, F。R. Shober, and R. F. Dickerson

High-purity single crystals of molybdenum are being prepared for irradiationdamage studies. A modified Andrade furnace, utilizing a steep temperature gradient along the length of the specimen to produce grain growth, has been constructed. The temperature gradient is obtained in the 1/8-in.-diameter molybdenum rod by water cooling the electrodes. An electric current is passed through the rod, and the specimen's resistance is utilized to obtain the temperatures necessary for grain growth.

The power required to grow single crystals of molybdenum has been established to be approximately $240 \mathrm{amp}$ at 2.5 to $3.0 \mathrm{~V}$. Specimens were run at this power for 1,2 , 3, 4, and $5 \mathrm{hr}$ and examined metallographically. The combination of $5 \mathrm{hr}$ at 240 amp and $2.5 \mathrm{v}$ produced single crystals approximately $2 \mathrm{in.}$ long and $1 / 8 \mathrm{in}$. in diameter. The existence of the single crystals was verified by sectioning the rod and examining its cross sections for evidence of grains. The absence of grain boundaries is considered to be evidence of a single crystal. At the present time four single crystals have been grown. Approximately a 50 pex cent yield has been obtained to date. Twelve single crystals of molybdenum will be grown.

Upon completion of the molybdenum crystal growth, an attempt to grow single crystals of alpha zirconium using the Andrade furnace will be made. Two methods will be investigated. A zirconium rod will be heated into the high-beta region and a single crystal of beta zirconium grown. The temperature of the crystal will then be reduced to that temperature corresponding to the high-alpha region and held. The length of time has not been determined. It is believed that the beta single crystal can be transformed to an alpha single crystal. A second method to be used will be to hold the temperature of 1/8-in.-diameter zirconium rod in the high-alpha range for several hours. 
$\mathrm{B}-1$

\title{
B. DEVELOPMENTS FOR ALUMINUM-CLAD FUEL ELEMENTS
}

\author{
R. J. Carlson and N. E. Daniel
}

A literature search and evaluation of the available data concerning the preparation and properties of UC has been completed. To supplement these data estimates are being made concerning the economic factors which will affect the choice of this material as a reactor fuel.

Aluminum-35 w/o uranium alloys containing 3 a/o and $3 \mathrm{w} / 0$ ternary additions are being investigated. The metallographic examinations of these alloys indicate that additions of this magnitude are the minimum necessary for the retention of $\mathrm{UAl}_{3}$. The losses incurred in centrifugally casting the binary aluminum-35 w/o uranium alloy have been determined.

\section{Preparation of Aluminum-Uranium Alloys}

N. E. Daniel, E. L. Foster, and R. F. Dickerson

Alloys of aluminum-uranium containing up to $20 \mathrm{w} / 0$ uranium have received widespread acceptance as fuels for use in low-temperature water-cooled and-moderated reactors. Continued interest in alloys of this system is reflected in current studies concerned with increasing the uranium content of the alloys, thereby increasing the density of the fuel loading of current and contemplated reactors. Two problems must be overcome if higher uranium alloys are to be cast satisfactorily. These are segregation and porosity. The se problems are intensified when castings of other than simple shapes are attempted. Current casting practice is confined to air melting and static casting into vertical molds. The work herein described is concerned with the development of centrifugal casting techniques. Among the advantages inherent in centrifugal casting when casting tubular shapes are the use of a permanent mold, the elimination of the center core, and the substitution of centrifugal force for the feeder head, thereby effecting a saving in materials. At this time the aluminum-35 w/o uranium alloy is being studied.

Since one of the major improvements that might be realized through the use of centrifugal casting techniques is a reduction in scrap and dross losses, metal losses during casting have been recorded. The major source of losses is in skulls in the pour cup and spout. It has been found that approximately $2.4 \mathrm{~kg}$ of remeltable material is normally left here during casting. Losses occurring during skimming prior to pouring are usually of the order of $0.06 \mathrm{~kg}$ when virgin materials are used. Losses increase significantly when remelt stock is used. Of course, there is also some material left in the crucible; this usually does not exceed $0.30 \mathrm{~kg}$. These weights were obtained from a series of castings poured at $2250 \mathrm{~F}$ into a steel mold preheated to 400 to $800 \mathrm{~F}$ and rotating at $700 \mathrm{rpm}$. It is significant that the weight of the skulls remained relatively constant regardless of the size of the casting produced.

Casting studies utilizing an 18-in.-long mold have produced castings with variations in wall thickness around their periphery and along their length. This variation in wall around the periphery of the castings was due to the nonconcentric rotation of the 
$B-2$

mold. The effects of this situation increased in severity with mold length. A new moldrotating device has been designed which should eliminate this difficulty.

The improvement of the casting and fabricating characteristics of aluminumuranium alloys by the addition of a third element is being attempted. Two series of alloys have been studied to date. The first series contained 3 a/o additions to the nominal aluminum- $35 \mathrm{w} / 0$ uranium alloy. The second series contained $3 \mathrm{w} / 0$ ternary additions. In many cases it was found that additions of 3 a/o led to the formation of a second compound which reduced the amount of matrix in the alloys. The metallographic examinations of the second series of alloys indicate that for the retention of $\mathrm{UAl}_{3}$ additions of $3 \mathrm{w} / \mathrm{o}$ or more of the elements evaluated will be required. It was also noted that the degree of refinement noted in the alloys containing tin and palladium was not as great in the second series as in the first.

Future work will be concerned with improving the casting techniques through modification of existing equipment so as to eliminate the aforementioned eccentricity. More emphasis will be placed upon obtaining fabricable alloys by using selected ternary additions. Among the additions to be evaluated are magnesium and lithium. Alloys will be fabricated and examined by metallographic techniques.

Literature Survey for the Appraisal of Uranium Monocarbide as a Possible Nuclear Fuel

J. B. Melehan, A. A. Bauer, and R. F. Dickerson

The literature-examination phase of this work has been terminated. To supplement information relating to the technology of uranium carbide, an estimate is being made of the effect of various economic factors, such as availability of material, methods, and costs of preparation and fabrication, on the economic feasibility of using this material as a reactor fuel. 


\title{
$\mathrm{C}-1$ \\ C. RADIOISOTOPE AND RADIATION APPLICATIONS
}

\author{
P. Schall
}

The study of uses of radioisotopes for quality control is currently directed toward three possible techniques applicable to the cement industry: (1) radiometric determination of magnesium, (2) activation analysis for various cement constituents, and (3) isotope-exchange techniques for calcium analysis. The first two techniques continue to look promising as methods for simplifying quality-control procedures. Studies on the third technique have not as yet progressed far enough to make an evaluation.

Irradiation of a number of urea inclusion compounds is in progress. Initial postirradiation analyses on the cetane-urea complex indicate that the most pronounced difference between complexed and uncomplexed cetane is the reaction between the host and guest molecules of the complex to form significant quantities of amides.

\section{Development of Radioactive-Tracer Quality-Control System.}

J. E. Howes, T. S. Elleman, C. T. Brown, D. N. Sunderman, and M. Pobereskin

A feasibility study of the neutron-activation method for the elemental analysis of portland cement has been completed and preliminary experiments have been initiated. A National Bureau of Standards cement sample was irradiated in the Battelle Reactor for $1 \mathrm{~min}$ and then transferred immediately to a 100-channel gamma-ray spectrometer. A camera mounted in front of the readout tube permitted rapid recording of the gross gamma spectrum from all the radionuclides. The change in gamma-energy spectrum was observed over a period of $2 \mathrm{hr}$, and the characteristic spectra were recorded. From these data, the degree of resolution of individual gamma-energy peaks was observed and the optimum decay time for the analysis of individual radionuclides was determined. The results indicated that conditions are favorable for the simultaneous, quantitative determination of aluminum, manganese, and sodium. Potassium and magnesium may be determined with less accuracy while the determination of calcium is still questionable.

In future work, the accuracy of the method will be determined using standard samples, and the limit of concentration for each element in the cement for application of this technique will be ascertained.

Development of the radiometric titration method for the determination of magnesium in cement has been continued. The procedure has been modified from that previously described in that the tracer dibasic ammonium phosphate solution was added to an acid $x$ ather than a basic solution of magnesium oxide. After an excess of the tracer solution was added, the insoluble magnesium ammonium phosphate compound was precipitated by the addition of ammonium hydroxide. The excess radiophosphorus was radioassayed with a solution-dip Geiger counter. This modification permitted a faster and cleaner separation of the magnesium from solution than the older method. Consecutive determinations of magnesium yielded reproducible results and agreement with the 
$\mathrm{C}-2$

calculated value appeared to be within 1 per cent. Efforts are currently being made to refine the titration procedure and to determine the limitations of the method.

Preliminary investigations of the analysis of calcium in calcium carbonate through solution exchange have been made. This work is not yet sufficiently advanced to permit an evaluation of the procedure.

\section{Radiation Chemistry of Inclusion Compounds}

M. J. Oestmann, J. L. McFariing, and W. S. Diethorn

Urea Compounds

The chemical analyses of irradiated and nonirradiated cetane, stearic acid, and the corresponding urea complexes were continued.

The cetane complex was dissolved in water to separate the organic phase from the urea. Infrared analysis of the organic phase showed the presence of transdouble bonds in an amount estimated to be about 3 to 4 per cent of the cetane. Gas chromatographic analysis verified this latter yield. Approximately the same amount and type of unsaturation was produced in the uncomplexed cetane ixradiated to the same dose $(2 \mathrm{x}$ $\left.10^{8} \mathrm{rads}\right)$. Infrared analysis of the irradiated cetane, after separation from the complex, showed that about 5 to 10 per cent of an amide, or a mixture of amides, had been produced. In a second sample of complexed cetane, irradiated to $3.7 \times 10^{8}$ rads, a 30 to 35 per cent yield of amide was observed. These amide yields will be verified by other analytical methods. Infrared analysis of an irradiated urea sample showed no evidence of a urea-urea reaction. Accordingly, these results show that urea and cetane in the complex react to form an amide or a mixture of amides in the presence of radiation. Next month an attempt will be made to separate and identify the mixture of unsaturated and amide structures believed to be present in this irradiated complex.

In the analysis of the irradiated stearic acid complex the separation of the organic phase has proven to be troublesome. Studies are being carried out to resolve this problem. These analytical difficulties have exhausted the supply of the irradiated complex, but a second irradiated sample of the complex will be available next month for these studies. An infrared analysis of irradiated, uncomplexed stearic acid has been completed in this phase of the program. There was no evidence of unsaturation after an exposure of $2 \times 10^{8}$ rads.

The urea complexes of heptane and amyl acetate prepared and reported in BMI1294 were found to be thermally unstable at room temperature. These complexes will not be studied further in the program.

Several additional urea complexes have been prepared and are now being irradiated in the cobalt-60 facility. These include the complexes of octane, decane, dodecane, oleic acid, octylchloroacetate, and a mixed complex of octane and dodecane. Additional samples of cetane and stearic acid complexes are also being irradiated. These complexes will be analyzed to determine the types and amounts of products formed during irradiation. 


\section{$\mathrm{C}-3$ and $\mathrm{C}-4$}

\section{Thiourea Compounds}

Thermal-stability tests on the nonirradiated thiourea complex of cumene show that this complex is unstable at room temperature. An attempt to prepare thiourea complexes of isooctyl alcohol and paramethylcyclohexanone were unsuccessful. Yields were too low for the requirements of the irradiation program. A small effort will be devoted to the search for more suitable thiourea complexes in the remainder of the calendar year, but the major effort during this period will be placed on the urea complexes. 


\section{$D-1$ and $D-2$ \\ D. PROCESSING OF FEED MATERIALS}

E. L. Foster

National Lead Company of Ohio in its operation of the Feed Material Production Center is concerned with the quality of unalloyed uranium fuel-slug material. A portion of this interest is reflected in its current sponsorship of a study to determine the mode of solidification in castings from which the fuel slugs are fabricated. The application of the results of this study to future casting needs is planned.

\section{Solidification of Uranium}

E. L. Foster, C. K. Franklin, B. L. Fletcher, B. Schwartz, and R. F. Dickerson

A study of the mechanisms by which uranium solidifies in a cylindrical mold is being made. The importance of such casting variables as superheat, mold shapes, and mold material is being evaluated and their effect on physical soundness of the casting determined. A governing factor on the freezing of the metal is the rate by which heat is extracted by the mold. A mathematical model has been developed to describe the heat flow in the ingot and mold during solidification of the metal. Temperature histories are being obtained experimentally on scaled-down ingots and molds. These thermal data will be used to refine and check the calculated results in the mathematical model.

Temperature measurements using 100-1b uranium melts are being made. The melts are poured into cold graphite molds using vacuum-induction-melting procedures. Each mold contains thermocouples arranged to measure center-line temperatures of the metal, ingot-mold interface, and the mold surfaces. In addition, a thermocouple is placed on the inside furnace jacket and above the ingot to obtain environmental temperatures. Presently thermal measurements have been obtained on two melts and the data are being evaluated. 
$E-1$ and $E-2$

\section{E. DEVELOPMENTS FOR LMFRE}

J. McCallum, R. W. Hardy, and C. L. Faust

Coatings of molybdenum compounds on Croloy 2-1/4 were studied as potential protective coatings against liquid bismuth. Molybdenum oxides were deposited electrolytically with the object of reducing it to metal after it was on the Croloy. However, the oxides were not reduced by liquid bismuth, sodium amalgams, sodium dispersions, lithium aluminum hydride, or liquid sodium.

Adherence of the molybdenum oxside to the Croloy is not completely satisfactory. Present efforts are directed toward improving this characteristic to the point where the oxide coating will provide adequate protection.

One molybdenum oxide coating was reduced to metal by hydrogen at $1050 \mathrm{~F}$. The metallic coating thus made was nonadherent.

While working with electrolytic deposition of molybdenum oxide, a bath composition was found which gave a deposit electrolessly. The surface of this electroless deposit is powdery but under the surface remains a coating that cannot be wiped off with a cleansing tissue. One $\mathrm{X}-\mathrm{r}$ ay test indicated the coating was $\mathrm{rich}$ in molybdenum but further chemical identification is required.

Thermodynamic calculations for the reduction of tantalum compounds showed them much more difficult to reduce than molybdenum compounds. Their solution chemistry, however, is less complex than the solution chemistry of molybdenum. Therefore, the kinetic problem may be more favorable for an electroless tantalum coating process. 
$\bullet$ 
$F-1$

F. RESEARCH FOR AEC REACTOR DEVELOPMENT DIVISION PROGRAM

S. J. Paprocki and R. F. Dickerson

REACTOR MATERIALS AND COMPONENTS

R. F. Dickerson

Current work on the study of valence effects of oxide additions to $\mathrm{UO}_{2}$ indicates that additions of $\mathrm{Y}_{2} \mathrm{O}_{3}$ are better stabilizers than $\mathrm{La}_{2} \mathrm{O}_{3}$ in $3000 \mathrm{~F}$ air; howevex, the homogeneity of the yttria additions does not appear as good. Experimental work has been in progress to determine the feasibility of utilizing a right-circular-cylinder die as a "pressure bomb". Results indicated that, although the technique is feasible, the pressures obtained were below those predicted for the advanced die design. Because of this, work on the right-cylinder-type die will not be continued. This advanced die is now nearly complete.

Study of the zirconium-uranium-hydrogen phase diagram has been continued and data are being correlated. Ir radiation of the two capsules containing hydrided zirconium -2 w/o uranium alloy has begun and initial data indicate that the desired temperatures are being reached.

The program concerned with irradiation of Type 347 stainless has been continued. The instrumented capsule which indicated thermocouple failure has been discharged from the reactor and is being sent to the Battelle Hot Cell. The capsule will be opened; the low-melting-temperature monitors and the thermocouple beads will be inspected. It is believed that from this inspection some indication of the operating temperatures experienced by the specimens will be obtained. If excessively high temperatures were not experienced, the remaining seven iron instrumented capsules will be inserted in the reactor.

\section{Valence Effects of Oxide Additions to Uranium Dioxice}

W. B. Wilson and C. M. Schwartz

Experimental work has continued to determine the effect of various oxide additives in stabilizing the $\mathrm{UO}_{2}$ fluorite structure. Previous studies of the $\mathrm{UO}_{2} \cdot \mathrm{La}_{2} \mathrm{O}_{3}$ system indicated that a sesquioxide additive to $\mathrm{UO}_{2}$ could maintain the fluorite structure under both oxidizing and reducing conditions, thereby preventing a transformation to the $\mathrm{U}_{3} \mathrm{O}_{8}$ structure. Current work has been directed toward (1) reduction of the amount of material necessary to achieve stabilization, (2) comparison of the oxidation characteristics of $\mathrm{La}_{2} \mathrm{O}_{3}$ additives to other additives such as $\mathrm{Y}_{2} \mathrm{O}_{3}, \mathrm{ThO}_{2}$, and $\mathrm{CaO}$, and (3) preparation of certain compositions of $\mathrm{La}_{2} \mathrm{O}_{3}$ additive for electrical studies.

A preliminary comparison of $\mathrm{UO}_{2}$ plus 40,50 , and 60 mole per cent $\mathrm{Y}_{2} \mathrm{O}_{3}$ to the same nominal compositions of $\mathrm{La}_{2} \mathrm{O}_{3}$ indicated slightly superior performance of the 
$F-2$

$\mathrm{Y}_{2} \mathrm{O}_{3}$-stabilized solid solutions to $3000 \mathrm{~F}$ air. Both additives were best at the higher 60 mole per cent composition. Metallographic and structural studies of the reduced $\mathrm{UO}_{2} \cdot \mathrm{Y}_{2} \mathrm{O}_{3}$ solid solutions indicated a lack of homogeneity not found for the $\mathrm{La}_{2} \mathrm{O}_{3}$ solid solutions. Raising the sintering temperature from 1700 to $1850 \mathrm{C}$ to achieve better homogeneity was only partially successful. The preliminary results tend to suggest that a solid immiscibility region may exist below $2000 \mathrm{C}$. Structural studies of the $\mathrm{UO}_{2} \cdot \mathrm{Y}_{2} \mathrm{O}_{3}$ compositions were also initiated for comparison with the $\mathrm{UO}_{2} \cdot \mathrm{La}_{2} \mathrm{O}_{3}$. Although the general features of both systems are similar, significant differences were found.

Preparation of samples to investigate the possibilities of reducing the amount of additive necessary to achieve stabilization was continued. In general, it is planned to substitute as much of a divalent material as is possible in place of the trivalent additive to achieve valence compensation. In addition, preparation of samples for electrical measurements containing 2,10 , and $20 \mathrm{w} / 0 \mathrm{La}_{2} \mathrm{O}_{3}$ was initiated. It is hoped that these compositions will provide a more detailed picture of the effect of $\mathrm{La}_{2} \mathrm{O}_{3}$ as an additive from pure $\mathrm{UO}_{2}$ to $\mathrm{UO}_{2}$ plus 60 mole per cent $\mathrm{La}_{2} \mathrm{O}_{3}$.

\section{High-Pressure High-Temperature Solid-State Studies}

W. B. Wilson and C. M. Schwartz

Pending the completion of an advanced die design, experimental work was conducted to determine the feasibility of utilizing a right-circular-cylinder-type die as a "bomb". In this technique the right-circular-cylinder piston is selected to have a height which is just sufficient to be pushed flush with the top of the die at its limit of strength, at which point it becomes completely supported. This occurs at roughly 40,000 atm. Further pressure may then be generated by internal heating. The results of the limited testing conducted indicated that, although the technique is quite feasible, it is experimentally difficult to obtain. Insulation breakdown was found to occur, in part due to the higher voltages necessary for heavy currents. The precise adjustment of piston length is also difficult. By use of the "friction hysteresis" effect it is estimated that approximately 53,000 atm were obtained. Since this is below the level of the advanced die design it is concluded that the right-circular-cylinder unit has but few advantages to warrant its continued use.

An experiment was conducted with a Bridgman-anvil-type unit to test the strength of the supporting structure for the new die design. The "supporting" structure held to the limits tested, but the carbide anvils failed at 1,250,000 psi $(85,000 \mathrm{~atm})$. Since this failure occurred at nominally a third of the right-circular-cylinder strength of the anvils, it was concluded that the radial stress determines the limit of failure in such a device. Additional support to contain the radial stress is necessary to achieve the upper limit of pressure for the Bridgman anvil, at approximately 250,000 atm.

Using the data obtained from the Bridgman anvil unit, attempts have been made to calculate the complete stress distribution in the new die design, including binding -ring stresses. The unit has been designed to utilize existing components and is interchangeable with them. Attempts have been made to eliminate expensive carbide where 
$\mathbf{F}-3$

possible. The present unit is nearly complete and, if successful, should permit the higher pressures desired and, perhaps more important, should be easier to instrument.

\section{Fueled Zirconium Hydride Moderator}

H. E. Bigony, A. K. Hopkins, and H. H. Krause

The study of fueled moderator compositions for potential use in gas-cooled reactors has continued. Additional measurements of hydrogen-absorption isotherms for the zirconium $-25 \mathrm{w} / 0$ uranium alloy have been made, and further work has been done on the high-temperature X-ray diffraction measurements. The two capsules which contain samples of a fueled moderator for radiation-damage studies are now in the MTR.

Structure and Pressure-CompositionTemperature Studies

Hydrogen-absorption isotherms were obtained at 650,676 , and $803 \mathrm{C}$. Sieverts plots of these data give boundary limits of single-phase and two-phase regions as shown in Table F-I. These boundaries a re designated numerically, as was done in the previous progress report (BMI-1294), because the phases present will need verification by $\mathrm{X}$-ray diffraction.

TABLE F-1. PHASE BOUNDARLES IN THE ZIRCONIUM-25 W/O URANIUM ALIOY HYDRIDE SYSTEM

\begin{tabular}{|c|c|c|c|c|c|c|}
\hline \multirow[b]{2}{*}{$\begin{array}{c}\text { Phase } \\
\text { Boundary } \\
\end{array}$} & \multicolumn{2}{|c|}{$650 \mathrm{C}$} & \multicolumn{2}{|c|}{$676 \mathrm{C}$} & \multicolumn{2}{|c|}{$803 \mathrm{C}$} \\
\hline & $\begin{array}{l}\text { Hydrogen } \\
\text { Absorption, } \\
\text { cm }^{3} \text { per } \mathrm{g}\end{array}$ & $\begin{array}{l}\text { Pressure, } \\
\mathrm{cm} \text { of } \mathrm{Hg}\end{array}$ & $\begin{array}{l}\text { Hydrogen } \\
\text { Absorption, } \\
\mathrm{cm}^{3} \text { per } 8 \\
\end{array}$ & $\begin{array}{l}\text { Pressure, } \\
\mathrm{cm} \text { of } \mathrm{Hg}\end{array}$ & $\begin{array}{l}\text { Hydrogen } \\
\text { Absorption, } \\
\mathrm{cm}^{3} \text { per g } \\
\end{array}$ & $\begin{array}{l}\text { Pressure, } \\
\mathrm{cm} \text { of } \mathrm{Hg}\end{array}$ \\
\hline 1 & 31.0 & 0.161 & 31.6 & 0.273 & 36.4 & 2.9 \\
\hline 2 & 57.7 & 0.164 & 57.5 & 0.301 & 46.9 & 2.9 \\
\hline 3 & 72.6 & 0.235 & 73.5 & 0.475 & 89.8 & 12.9 \\
\hline 1 & 127.3 & 0.250 & $128 . t$ & 0.510 & 130.2 & 13.25 \\
\hline
\end{tabular}

High-temperature X-ray patterns were made on samples of hydrided zirconium-1 w/o uranium and $-50 \mathrm{w} / 0$ uranium alloys. The processing of these data to identify the structures is under way.

The hydrogen-absorption isotherms of the $25 \mathrm{w} / 0$ alloy will be measured at temperatures below $650 \mathrm{C}$. The high-temperature $\mathrm{X}-\mathrm{xay}$ diffraction investigation of the zirconium-uranium alloys will proceed as rapidly as conditions permit. 
Radiation-Damage Studies

Irradiation of the two capsules (BMI-20-1 and BMI-20-2) containing hydrided zirconium-2 w/o uranium alloy has begun in the MTR. Initial data on specimen temperatures indicate that the desired temperatures are being reached. The radiation exposure will be continued to a burnup of $20 \mathrm{a} / 0$ of the uranium.

\section{Irradiation Surveillance Program on Type 347 Stainless Stee1}

F. R. Shober, A. W. Hare, F. A. Rough, and R. F. Dickers on

An investigation is being made of the effect of irradiation damage on the mechanical properties of AISI Type 347 stainless steel. The tensile cyclic-strain fatigue and impact properties are to be determined after exposures to neutron fluxes generally representing a 6 -month exposure in the $F-10$ position. Irradiations are to be done at two temperatures: at process-water temperature (approximately $120 \mathrm{~F}$ ) and at $600 \mathrm{~F}$. It is expected that the properties will be determined after total integrated fluxes of $2.4,2.8,7.2,9.6,12$, and $14.7 \times 10^{22}$ nvt.

Eight capsules containing tensile cyclic-strain fatigue and impact specimens are being irradiated at process -water temperature in the $F=10-N E$ and $F-10-S E$ positions. These capsules will be discharged at intervals to represent 6 months of exposure of the KAPL 33 loop and the mechanical properties will be determined to show changes that are associated with these exposures.

The instrumented capsule (BMI-24-17), containing tensile and cyclic-strain fatigue specimens, four Chromel-Alumel thermocouples, and four low-melting metals and alloys, has been discharged after two cycles in the F-10-NW position. This capsule had been inserted originally to monitor temperature for comparison with the gamma-flux measurements. The construction of the lead capsule was representative of seven other nonlead capsules that had been designed and constructed to operate at $600 \mathrm{~F}$ in the gamma fluxes of the ETR. The measured gamma flux for this position was somewhat lower than expected and design temperatures probably will not be achieved. The temperature-monitoring test was to establish approximately at what temperatures the "hot" capsules would be irradiated. The failure of all four thermocouples occurred before adequate temperature measurements could be made, consequently the seven nonlead hot capsules were not loaded in the reactor. The lead capsule is being returned to the Battelle Hot Cell where the temperature monitors (the low-melting metals) will be checked in an attempt to determine what temperatures the capsules experienced. The thermocouple beads will also be inspected. This inspection of the thermocouples and the materials in the vicinity of them is an effort to determine the causes of failure of the thermocouples. If it appears that excessively high temperatures were not experienced by the lead capsule, the seven nonlead capsules will be inserted in $F-10-S W$ and $F-10-N W$ positions, and a third lead capsule will be constructed to determine temperature of irradiation in the test position. 


\title{
$F-5$
}

\section{STUDIES OF ALLOY FUELS}

\author{
R. F. Dickers on
}

\begin{abstract}
Niobium-uranium alloys containing 20,30,40,50,60, and $70 \mathrm{w} / \mathrm{o}$ uranium have been prepared in small heats. Hot -hardness data indicate that alloys containing less than $40 \mathrm{w} / 0$ uranium should fabricate the same as the niobium base material. If this is true, the material should take cold rolling to a large reduction after initial breakdown is accomplished. Large heats of the alloys made from three types of niobium have been prepared and full-scale evaluation is being initiated.

All of the alloys initially planned for the thorium-alloy study have been prepared. These include binary thorium-uranium alloys, ternary alloys with molybdenum, niobium or zirconium additions, and some quaternary alloys. All alloys except the thorium $-10 \mathrm{w} / 0$ uranium $-2 \mathrm{w} / 0$ niobium $-5 \mathrm{w} / 0$ zirconium and the thorium $-10 \mathrm{w} / 0$ uranium $-2 \mathrm{w} / 0$ niobium $-10 \mathrm{w} / 0$ zirconium alloys were readily fabricated. Corrosion specimens from all zirrconium-containing alloys have been heat treated and are ready for corrosion testing. Preliminary hot-hardness data indicate that the zirconium additions have a considerable hardening effect.
\end{abstract}

\section{Development of Niobium-Uranium Alloys}

J. A. DeMastry, F.R. Shober, and R. F. Dickerson

An investigation of the mechanical and physical properties of alloys in the niobium $-x i c h$ portion of the uranium phase diagram is expected to provide needed information for the preparation of reactor fuels. A limited amount of work has been reported for alloys of these compositions. Examination of reported data indicates that the properties of niobium alloys are influenced by the purity of both the uranium and niobium used in alloying. Therefore, the effects of oxygen and zirconium, the major impurities in niobium, are to be evaluated. A study of fabrication characteristics, mechanical and physical properties, and corrosion behavior in water, sodium, carbon dioxide, and air is to be made.

The effects of impurities are being investigated by using three grades of niobium as base materials for alloy preparation. These three grades consist of high-purity niobium containing less than $300 \mathrm{ppm}$ oxygen and less than $100 \mathrm{ppm}$ zirconium, a second grade containing $700 \mathrm{ppm}$ oxygen and $0.17 \mathrm{w} / 0$ zirconium, and a third grade containing $600 \mathrm{ppm}$ oxygen and $0.7 \mathrm{w} / 0$ zirconium.

Hot-hardness data on the alloys using high-purity niobium as a base material and containing $0,20,30,40,50,60$, and $70 \mathrm{w} / 0$ uranium have been collected. Evaluation of these data indicates that alloys containing less than $40 \mathrm{w} / 0$ uranium will have to be fabricated the same as the niobium base material. If this is true, it indicates that, after the cast structure is broken down, it may be possible that the se alloys can then be cold rolled to large reductions without annealing. Attempts to break down the cast structure will be made by press forging the niobium-uranium alloy ingots at $900 \mathrm{C}$. The 
ingots will be protected from contamination by molybdenum cans. Rod rolling in molybdenum cans will also be used in attempts to accomplish the breakdown. Alloys containing more than $40 \mathrm{w} / 0$ uranium will be rod rolled in molybdenum cans at higher temperatures (11.00 to $1300 \mathrm{C}$ ).

Alloys containing 30, 20, and $10 \mathrm{w} / 0$ uranium with both the high-and lowzirconium-bearing niobium as a base have been single consumably melted, and are now being remelted. Alloys containing 60, 50, and $40 \mathrm{w} / 0$ uranium with all three grades of niobium as the base material and alloys containing 30,20 , and $10 \mathrm{w} / 0$ uranium with high-purity niobium as a base are now in the process of being melted.

\section{Development of Thorium-Uranium Alloys}

V. W. Storhok, A. A. Bauer, and R. F. Dickerson

A program aimed at improving the irradiation stability and corrosion resistance of thorium-uranium alloys is being conducted. Approaches being considered are control of uranium distribution, alloying to stabilize gamma in the uranium phase, alloying to strengthen the matrix, and quaternary alloying to achieve a combination of strengthening and gamma-uranium-phase stabilization.

Binary alloys are being studied to determine the effects of impurities, melting techniques, fabrication, and heat treatment on uranium distribution. Since metallography is perhaps the major tool suitable for this study, a satisfactory metallographic technique for thorium alloys is being developed. The most promising technique developed to date involves vibratory polishing and vacuum cathodic etching.

All the initially planned binary alloys, ternary alloys with molybdenum, niobium, or zirconium additions, and quaternary alloys containing both zirconium and niobium have been prepared by arc-melting techniques. With two exceptions, all the alloys also have been successfully hot rolled. A thorium-10 w/o uranium $-2 \mathrm{w} / 0$ niobium $-5 \mathrm{w} / \mathrm{o}$ zirconium alloy and a thorium $-10 \mathrm{w} / 0$ uranium $-2 \mathrm{w} / 0$ niobium $-10 \mathrm{w} / 0$ zirconium alloy cracked when rolled at $1800 \mathrm{~F}$. These two alloys are being remelted and further attempts to fabricate them will be made. The binary alloys are being cold reduced in preparation for recrystallization studies. Also, all alloys are being subjected to various heat treatments to determine effects on structure.

Corrosion specimens from all alloys containing zirconium have been heat treated $24 \mathrm{hr}$ at $1000 \mathrm{C}$ and furnace cooled or water quenched. These will be corrosion tested in $200 \mathrm{C}$ water. On the basis of initial results, additional heat treatments may be planned.

Hot-hardness measurements are being made on all alloys. Data available to date indicate zirconium has a considerable hardening effect, particularly at lower temperatures. At $600 \mathrm{C}$, a thorium-10 w/o uranium-10 w/o zirconium alloy and a thorium-20 w/o uranium $-20 \mathrm{w} / 0$ zirconium alloy each exhibited a hardness of approximately 65 DPHN. At room temperature, diamond pyramid hardness numbers of 161 and 226 were observed. Neither molybdenum nor niobium appears to have appreciable hardening effects. 


\section{GENERAL FUEL-ELEMENT DEVELOPMENT}

S. J. Paprocki

Cermet fuel materials consisting of from 60 to 90 volume per cent of $\mathrm{UO}_{2}$, UN, or UC dispersed in stainless steel are of interest, as they combine some of the advantages of both the ceramic and dispersion fuels. Gas-pressure bonding and swaging are being investigated as methods for densifying and cladding these cermet fuels. Attempts are being made to obtain accurate measurements of the electrical resistivity of these materials for estimating thermal-conductivity values.

The gas-pressure bonding technique is being investigated as a method for the cladding and joining of niobium fuel elements and assemblies. Initial studies have been concerned with the self-bonding of niobium and molybdenum. Ductile bonds possessing complete grain growth across the original interface have been obtained between molybdenum plates pressure bonded at $2100 \mathrm{~F}$ with 10,000 psi of helium. Niobium plates, pressure bonded under the same conditions, exhibited a brittle bond with only slight grain growth across the bond interface.

The gas-pressure bonding process occurs in several stages. In the initial stage, deformation brings the bonding surfaces into intimate contact. At this point, surface phenomena and diffusion govern the completion of the bonding cycle. Studies are in progress to obtain a better understanding of these processes in order that the optimum bonding conditions for any material can be related to its physical and mechanical properties.

\section{Fabrication of Cermet Fuel Elements}

S. J. Paprocki, D. L. Keller, G.W. Cunningham, and D. E. Kizer

Techniques for the fabrication of fuel elements containing cores with 60 to 90 volume per cent of ceramic fuel dispersed in a metallic matrix are being investigated. Evaluations are based upon microstructures and physical and mechanical properties. Fuel elements are being made in the shape of pins as well as plates. Since previous results have shown that simultaneous application of heat and pressure produces better core structures than sintering, all cores for fuel-element fabrication are being prepared by hot-pressing techniques. However, feasibility studies on sintering and infiltration are being continued.

Swaging and gas-pressure-bonding techniques are being used to prepare fuelelement pins. Green cores (80 volume per cent in a stainless matrix) with densities of 55 per cent of theoretical were placed in stainless tubing and held for $3 \mathrm{hr}$ at $2100 \mathrm{~F}$ in a gas pressure of 10,000 psi. Core densities of 83 per cent of theoretical were obtained. Green cores containing 60 and 90 volume per cent $\mathrm{UO}_{2}$, and pressed to 75 per cent of theoretical density, have been placed in stainless tubes and will be pressure bonded under the same conditions listed above. Green compacts containing 80 volume per cent $\mathrm{UO}_{2}$, UN, or UC have been prepared for hot swaging studies. If high densities 
$F-8$

cannot be obtained by swaging alone, these pins will be submitted for a final gaspressure bonding treatment.

Sections of flat plates have been fabricated by pressure bonding 90 per cent dense press-forged cores. Larger plates ( 2 in. wide by 6 to 8 in. long) containing compartmented cores are being prepared for pressure bonding. Pressure bonding of flat plates containing green cores will also be investigated.

In addition, attempts to obtain more accurately measured transverse and longitudinal electrical resistances of hot-pressed $\mathrm{UO}_{2}$-stainless steel cermets are being made. Attempts to attach copper blocks to the faces of the cermets by soft soldering to reduce contact resistance were unsuccessful due to inadequate wetting of the cermet by the solder. Diffusion bonding for $1-1 / 2 \mathrm{hr}$ in a dry-hydrogen atmosphere at $1900 \mathrm{~F}$ appears to be a satisfactory method of attaching the copper contact blocks to the cermet; however, a complete evaluation of the bond interface has not been made.

Gas-Pressure Bonding of Molybdenum- and Niobium-Clad Fuel Elements

S. J. Paprocki, E. S. Hodge, C. B. Boyer, and R. W. Getz

Molybdenum and niobium are promising cladding and structural materials for high-temperature-reactor application. They retain their strength at elevated temperatures and possess favorable nuclear propexties. The use of these matexials in oxidizing environments has been considered; however, for such application, they must be protected with an oxidation-resistant cladding. For other applications, such as use in an inert-gas-cooled or liquid-metal-cooled reactors, niobium and molybdenum can be utilized in bare form; however, there are no available satisfactory techniques for fabricating molybdenum- or niobium-clad fuel elements and as semblies. During fabrication, the niobium and molybdenum generally alloy with the container materials and distort because of the dissimilar fabrication characteristics of the two materials. The gas pressure-bonding process appears extremely promising for the preparation of niobium and molybdenum fuel assemblies. In this process, the components are fabricated to final size, assembled in a leaktight container, and subjected to gas pressure at an elevated temperature. The gas pressure brings the components into the intimate contact that is necessary for diffusion to occur and form a solid-state metallurgical bond.

The first phase of this investigation is concerned with the self-bonding of molybdenum and niobium. This study includes a determination of gas-pressure-bonding parameters, and an investigation of the effects of prior fabrication and surface conditioning.

A ductile bond possessing complete grain growth across the original interface was obtained by pressure bonding of two edge-welded molybdenum plates for $3 \mathrm{hr}$ at $2100 \mathrm{~F}$ with 10,000 psi of helium. These plates were cold worked and pickled in a solution containing 95 parts $\mathrm{H}_{2} \mathrm{SO}_{4}, 4.5$ parts $\mathrm{HNO}_{3}, 0.5$ parts $\mathrm{HF}$, and $18.8 \mathrm{~g}$ per liter $\mathrm{Cr}_{2} \mathrm{O}_{3}$ prior to bonding. It is significant that a ductile bond was achieved as almost all other joining techniques tend to embrittle the molybdenum. 
Niobium plates, cold reduced 90 per cent, were pickled for $1 \mathrm{hr}$ at room temperature in a 20 volume per cent HF-water solution, washed, and assembled in TiNamel containers that were evacuated and sealed. Specimens prepared from this material were pressure bonded for $6 \mathrm{hr}$ at $1800 \mathrm{~F}, 4 \mathrm{hr}$ at $1900 \mathrm{~F}$, and $3 \mathrm{hr}$ at $2000 \mathrm{~F}$. Specimens that were run at $1800 \mathrm{~F}$ were not completely recrystallized and exhibited only partial bonding of the niobium to itself with only slight grain growth across the interface. The specimens bonded at 1900 and $2000 \mathrm{~F}$ were completely recrystallized, but there was little improvement in the amount of grain growth across the interface as compared with specimens bonded at $1800 \mathrm{~F}$. It is believed that the purity of the niobium will influence the bonding results. These studies were conducted with doublesintered niobium. Double electron-beam melted niobium has been received and will be used in all future specimens. The effect of cold work, surface conditioning, and sur face roughness on the self-bonding properties of niobium will be further investigated using this material.

Some cursory studies have been conducted to evaluate the feasibility of using a diffusion brazing technique for promoting bonding. This technique involves the use of a low-melting phase at the bond interface to promote wetting of the two surfaces. A very small amount is utilized so that this low-melting phase is completely diffused away from the interface during the bonding treatment.

Molybdenum plates with either a copper, iron, or nickel braze layer of approximately $0.001 \mathrm{in}$. in thickness were pressure bonded at $1800 \mathrm{~F}$ for $6 \mathrm{hr}$ at 10,000 psi. Partial bonding was achieved in all of the specimens. The resultant specimens were pressure bonded at $2100 \mathrm{~F}$ for $3 \mathrm{hr}$ at $10,000 \mathrm{psi}$ in an effort to diffuse the braze layer. Examination of these specimens revealed that extensive diffusion had occurred, but a portion of the braze layer was still present at the interface. Thinner electroplated coatings of chromium, copper, iron, and nickel will be investigated. It is anticipated that these electroplated layexs can be completely diffused away from the bond area.

Basic Studies of Pressure Bonding

S. J. Paprocki, E. S. Hodge, S. D. Beck, M. A. Gedwill, and D. H. Fisher

An investigation is being conducted in order to analyze the deformations associated with the pressure-bonding process. Due to the hydrostatic nature of the applied pressure, relatively small deformations occur. However, the surfaces to be bonded are more or less rough; thus a necessary condition for bonding is that the mating sur faces deform sufficiently to attain intimate contact.

\section{Analytic Studies of Pressure Bonding}

In order to develop an analytic approach to the question of surface deformations, it is necessary to establish both an idealized physical model to represent the mechanical behavior of the material and a geometrical model to represent the surface ir regularities. 
$F-10$

The material behavior is assumed to be characterized by the power law for second-stage creep. Although it is recognized that this law is not generally correct under all conditions it seems to be the best choice for application to complex stress configurations with reasonable effort, where deformation rates are involved.

The geometry of the surfaces is being represented by a set of infinitely thickwalled elliptic cylinders. The creep behavior of the elliptic cylinder is now being studied analytically. Due to the complexity of the differential equations, an exact solution is impossible, even with the idealized creep law. However, a variational principle is being used to obtain an approximate solution. The variational principle refers to a technique whereby the stress and strain configurations are assumed in terms of certain parameters. The potential and complementary energies are computed and then minimized. If a good choice of configurations is made, an upper and lower bound for the creep rate in terms of the pressure will be found, these limits hopefully being not too far apart. The solution to this problem is not quite complete, so no results may be reported at this time.

\section{Experimental Studies of Pressure Bonding}

Tests have been run in an effort to determine the parameters for the power creep law for $2 S$ aluminum at 500 and $700 \mathrm{~F}$. The data have not been completely analyzed but there seems to be the expected linear relationships between the torque and the logarithm of the angular velocity. When these data are examined in detail, it will then be possible to compute the deformations of circular cylinders in terms of the pressure. These computed deformations may then be compared with previously obtained experimental data in order to evaluate the validity of applying the creep laws obtained from torsion tests to creep behavior under hydrostatic pressure.

\section{Factors Affecting Pressure Bonding}

\section{G. W. Cunningham}

Studies on the fundamentals of pressure bonding were initiated in the last fiscal year and two correlated programs were conducted: one investigation was primarily concerned with evaluation of factors such as surface preparation and heat treatment as related to gas-pressure bonding; the second investigation was primarily concerned with the development of a relationship between some property of the metal and its bonding characteristics. The work on the second program has been directed toward the development of a relationship to predict the rate of closure of macroscopic voids and ultimately the intimate contact of the metal surfaces at a particulax temperature and various pressures. This work is continuing and the progress is reported in another section. The value of such a relationship will be greatest in the very early stages when little or no diffusion has taken place. In the empirical study, several interesting results were obtained concerning grain growth and presence of impurities or voids at the bond line. Such factors must be considered in any further studies on bonding. In the program reported in this section, emphasis will be placed on intermediate and final stages of the solid-phase bonding of metals. The study has as an objective the gaining of information 


$$
F-11 \text { and } F-12
$$

leading to a relationship which will allow prediction of conditions necessary to obtain complete solid-phase bonding between two metals.

Much of the previous work has been conducted with zirconium or Zircaloy-2, and structures have been examined with both the light microscope and the electron microscope. The electron-micros copy study indicated that what appears to be lines of impurities at the bond interface may actually be rows of small voids. However, the results are not conclusive since etching was required to show the voids. Therefore, it appears necessary before attempting to establish a theory for the bonding mechanism, to clearly establish the factors involved.

The first approach will be to establish whether similar defects occur in a basic metal such as copper for which a great deal of property data (self-diffusion coefficients, creep strength, etc.) are available. Also, etchants are available for producing dislocation pits, and if voids occur it should be possible to verify whether or not they are a result of clusters of dislocations.

Copper specimens in which both plates contain similar grain size and structure but one of which has a 500- $\mu \mathrm{in}$. rms shaped surface and the other has an $8-\mu \mathrm{in}$. rms ground surface are being prepared and will be hot pressed in vacuo for the initial study. 


\section{$G-1$ and $G-2$ \\ G. FATIGUE STUDIES OF INCONEL AND INOR-8}

R. G. Carlson

\section{Fatigue Studies of Incone1}

This program has the objectives of obtaining basic fatigue information on Inconel and of establishing quantitative relationships among the variables of temperature, stress, strain, time, and cyclic frequency for Inconel. The current phase of the program is conceived with measuring and recording strain associated with the cyclic portion of a combined load.

During the past month work was begun to obtain significant S-N (stress-number of cycles) data. Two specimens were stress cycled at $1500 \mathrm{~F}$, and the stress-strain histories were recorded for the entire lifetime of each specimen. The information recorded was then studied to obtain hysteresis plots and other data of interest.

Next month this work will be continued to obtain additional $S-N$ data.

\section{Fatigue Studies of INOR-8}

This program is concerned with the investigation of temperature and frequency dependence of fatigue properties of INOR -8 alloy.

Last month a supply of INOR-8 was received. Fatigue specimens are now being machined from this material. A limited number of tests were made on specimens machined from material remaining from the preliminary studies.

Next month the accumulation of data will begin, using the new supply of specimens. Tests will be run at 100 and $10,000 \mathrm{rpm}$. 


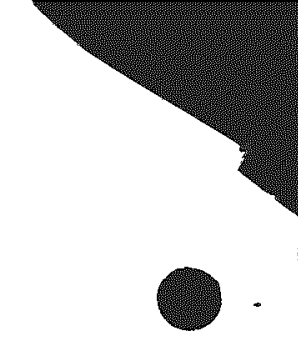


$\mathrm{H}-1$

\section{H. PHYSICAL RESEARCH}

F. A. Rough

In this section is reported progress on physical research which is part of the AEC Division of Research program.

The reports this month include those on "Niobium-Gas Reactions", where the concern is the mechanism of reaction of nitrogen with niobium, and "Constitution of Niobium-Uranium Alloys", where the concern is the evaluation of the effect of the contaminating elements, oxygen and nitrogen, on the constitution of these alloys.

Detailed reports are not included this month on the remaining two programs, but will be included next month.

\section{Niobium-Gas Reactions}

W. M. Albrecht and W. D. Goode

This is a study of the kinetics and mechanism of the reaction of nitrogen with niobium. The study includes measuring the diffusion coefficient for nitrogen in the metal.

Kinetic experiments are being made by measuring the rate of nitrogen uptake in a modified Sieverts apparatus (volumetric technique) and a microbalance (gravimetric technique). Both techniques are being used so that kinetic data can be obtained over a wide temperature range (about 500 to $1400 \mathrm{C}$ ). Preliminary data have been obtained using cylindrical specimens $(0.3$ to $1.0 \mathrm{~cm}$ in diameter) at $1 \mathrm{~atm}$ of nitrogen pressure at $900,1000,1200,1300$, and $1400 \mathrm{C}$. The data follow the parabolic law, $\mathrm{w}^{2}=\mathrm{kt}$, where $w$ is the amount of nitrogen reacting per unit surface area, $k$ is the parabolic rate constant, and $t$ is time. The parabolic rate constants range from about 0.69 $\left(\mu \mathrm{g} / \mathrm{cm}^{2}\right)^{2}$ per sec at $900 \mathrm{C}$ to $2.0 \times 10^{3}\left(\mu \mathrm{g} / \mathrm{cm}^{2}\right)^{2}$ per sec at $1400 \mathrm{C}$. X-ray diffraction investigation of the nitride film produced at $1000 \mathrm{C}$ in $3 \mathrm{hr}$ showed both $\mathrm{Nb}_{2} \mathrm{~N}$ and $\mathrm{NbN}$ as reaction products. Further studies are being made of the reaction kinetics and of the composition and structure of the nitride film.

Studies of the diffusion of nitrogen in niobium are being made using the concentration gradient technique in which a cylindrical specimen is heated in a nitrogen atmosphere for a predetermined length of time. The diffusion coefficient for nitrogen in the metal is then determined from analysis of layers machined radially from the specimen. A specimen has been reacted at $1400 \mathrm{C}$ and is presently being machined into layers. The information obtained from this specimen will be used as a guide to selection of diffusion times for other specimens. 
$\mathrm{H}-2$

\section{Constitution of Uranium-Niobium Alloys}

S. G. Epstein, A. A. Bauer, and R. F. Dickerson

A study of the uranium-niobium constitutional diagram is being performed.

An alloy containing $6 \mathrm{w} / 0$ niobium was studied for phase transformations from 900 to $620 \mathrm{C}$ by high-temperature $\mathrm{X}$-ray diffraction. No evidence was observed for the formation of a tetragonal structure as has been previously reported. This structure is believed to be a transition-type structure which is obtained on quenching and which precedes the formation of alpha uranium and gamma 2 .

Diffusion couples of uranium-niobium have been heat treated at 900,925 , and $1000 \mathrm{C}$ for 168,170 , and $50 \mathrm{hr}$, respectively. Very broad diffusion zones have been observed in the couples. Data have been taken for the couple annealed at $925 \mathrm{C}$ by the electron-beam probe, and the data appear to indicate a very narrow two-phase region, approximately $5 \mathrm{w} / 0$ in width, at this temperature. Closer analysis of the data and calibration of the electron-beam probe will present a clearer interpretation of this region, and may reveal its composition limits. The other couples will also be analyzed by the electron-beam probe.

Initial thermal analyses of the low-niobium alloys have indicated a monotectoid transformation temperature of $647 \mathrm{C}$ for a $2 \mathrm{w} / \mathrm{o}$ niobium alloy and $650 \mathrm{C}$ for a $6 \mathrm{w} / \mathrm{o}$ niobium alloy; an alpha-to-beta transformation temperature of $672 \mathrm{C}$ is indicated for the $2 \mathrm{w} / \mathrm{o}$ niobium alloy. Alloys containing $2 \mathrm{w} / \mathrm{o}$ niobium are being studied metallographically for confirmation of the transformation temperatures. 
I- 1

\section{SOLID HOMOGENEOUS FUELED REACTORS}

W. H. Goldthwaite

Fueled graphite spheres, 1-1/2 in. in diameter, are being considered as the fuel elements of a proposed pebble-bed reactor. The effects of irradiation on the fissiongas retention, distortion and mechanical properties of several varieties of this type fuel element are being investigated.

\section{Fabrication and Pre-Exposure Evaluation}

W. C. Riley, A. J. Roese, J. F. Lynch, and W. H. Duckworth

Battelle has prepared two types of experimental graphite fuel elements for irradiation testing. Both types are $1-1 / 2 \mathrm{in}$. in diameter and contain $4.4 \mathrm{~g}$ of uranium235. In one type, the fuel, in the form of $\mathrm{UO}_{2}$ particles, is dispersed in a spherical graphite core $1 \mathrm{in}$. in diameter. The core is contained in an unfueled graphite shell 1-1/2 in. in outside diameter. The other type is a uniform dispersion of $\mathrm{UC}_{2}$ in $\mathrm{graph}-$ ite. Uranium dioxide was mixed with the binder and filler during fabrication and converted to $\mathrm{UC}_{2}$ in situ. A brief description of the raw materials and fabrication techniques used for preparation of each type of fueled graphite is presented in Table I- 1 .

During baking, an unscheduled temperature rise from 275 to $525 \mathrm{~F}$ occurred during a period of $1 \mathrm{hr}$. This is believed to be the cause of cracking in the shells of 10 of the 12 fueled core samples. The samples containing a uniform fuel dispersion had no visible structural defects.

The fueled core specimens prepared at Battelle and fueled graphite specimens furnished by vendors have been tested for abrasion resistance and impact resistance.

Relative abrasion resistance was estimated from weight loss caused by tumbling the test specimens in a rubber-lined drum containing a number of dummy graphite spheres. Current results indicate that the spheres containing a uniform dispersion of $\mathrm{UO}_{2}$ furnished by the National Carbon Company have the best abrasion resistance. Most of the tests to date indicate that the Syl-Cor balls are more abrasion resistant than the Battelle balls. However, there is appreciable variation between balls of a given type.

Impact resistance was measured by dropping a 6-1/4-1b weight on the specimen, with the height of the dropped weight a controlled variable. The breaking loads for the National Carbon balls, the Syl-Cor balls, and the Battelle fueled core balls were 7.3, 14.9 , and $3.2 \mathrm{ft}-1 \mathrm{~b}$, respectively. 
TABLE I-1. FABRICATION OF FUELED GRAPHTTE SPHERES

\begin{tabular}{|c|c|c|c|c|c|c|c|c|}
\hline $\begin{array}{l}\text { Type of } \\
\text { Fuel Element }\end{array}$ & $\begin{array}{c}\text { Type of } \\
\text { Raw Materials } \\
\text { for Fuel Matrix }\end{array}$ & $\begin{array}{l}\text { Diameter } \\
\text { of Fueled } \\
\text { Sphere, } \\
\text { in. }\end{array}$ & Fuel Form & $\begin{array}{l}\text { Amount } \\
\text { of Fuel, } \\
g\end{array}$ & $\begin{array}{l}\text { Type of } \\
\text { Raw Materials } \\
\text { Used for } \\
\text { Outer Shell }\end{array}$ & $\begin{array}{c}\text { Shell } \\
\text { Thickness. } \\
\text { in. }\end{array}$ & $\begin{array}{l}\text { Forming } \\
\text { Pressure, } \\
\text { psi }\end{array}$ & $\begin{array}{l}\text { Temperature } \\
\text { of Maximum } \\
\text { Heat Treatment, } \\
\text { F }\end{array}$ \\
\hline $\begin{array}{l}\text { Fueled } \\
\text { spherical } \\
\text { core }\end{array}$ & $\begin{array}{l}\text { 79L resin( }(a) \text { coke bonded } \\
\text { with } B V-1600(b) \text { resin }\end{array}$ & 1.0 & $\mathrm{UO}_{2}$ & 4.4 & $\begin{array}{l}\text { AGOT graphite } \\
\text { bonded with } \\
\text { BV }-1600 \text { resin }\end{array}$ & 0.25 & 10,000 & 2000 \\
\hline $\begin{array}{l}\text { Uniform fuel } \\
\text { dispersion }\end{array}$ & $\begin{array}{l}\text { Texas petroleum coke, } \\
55 \text { per cent minus } 200 \\
\text { mesh, bonded with } \\
\text { Barrett medium-hard } \\
\text { coal-tar pitch }\end{array}$ & 1.5 & $\mathrm{UC}_{2}$ & 4.4 & None & -- & 10,000 & 4660 \\
\hline
\end{tabular}

(a) 79L resin is a phenolic resin made by Ironside Company, Columbus, Ohio.

(b) BV -1600 resin is a phenolic resin made by Bakelite Division of Union Carbide Corporation. 
$I-3$

\section{Encapsulation and Irradiation}

G. E. Raines, J. W. Kisse1, and J. H. Stang

The capsule for the irradiation of six fueled graphite spheres $(1-1 / 2$ in. in diameter) was installed in a core position of the Battelle Research Reactor. Table I-2 lists estimated performance data for the capsule from $40 \mathrm{hr}$ after the start of the irradiation to the end of October. Initially, the temperatures were from 100 to $200 \mathrm{~F}$ higher than those listed; after about $40 \mathrm{hr}$, the listed values were reached and subsequently the fluctuations have been of a minor nature. Some of the original decline is probably attributable to a poisoning effect, the most important poison being Xenon-135. Since this is a relatively short half-life isotope, saturation is approached in a relatively short period.

The irradiation is planned to continue until December 1, 1958, with examination of the various specimens in the hot cell scheduled to follow immediately. The burnup predicted, based on an irradiation of $40 \mathrm{hr}$ and an average heat generation of $1.5 \mathrm{kw}$ per specimen, is of the order of 1.5 per cent of the Uranium-235 present.

\section{Postirradiation Examination}

R. J. Burian and J.E. Gates

Preparations for the postirradiation examination of the six spherical specimens composed of $\mathrm{UO}_{2}$ dispersed in graphite are approaching completion. 
TABLE 1-2. PERFORMANCE ESTIMATED FOR THE SIX SPECIMENS IN CAPSULE BRR-SP-1

Nominal Uranium (Fully Enriched) Content is $4-3 / 4 \mathrm{G}$ per Specimen

\begin{tabular}{|c|c|c|c|c|c|c|}
\hline \multirow{2}{*}{$\begin{array}{c}\text { Specimen } \\
\text { Designation(a) }\end{array}$} & \multirow[b]{2}{*}{ Fabricator } & \multirow[b]{2}{*}{ General Description } & \multirow{2}{*}{$\begin{array}{l}\text { Estimated Heat } \\
\text { Generation }(b) \\
k w\end{array}$} & \multicolumn{3}{|c|}{$\begin{array}{l}\text { Estimated Surface Temperatures at } \\
\text { Equator of Specimen }(c), \bar{F}\end{array}$} \\
\hline & & & & Maximum & Nominal & Minimum \\
\hline $\mathrm{NC}-86$ & National Carbon Co. & Uniform mixture of $\mathrm{UO}_{2}$ and graphite & 1.4 & 1260 & 1125 & 1090 \\
\hline NC -87 & National Carbon Co. & Ditto & 1.5 & 1325 & 1190 & 1140 \\
\hline 12 & Battelle & $\begin{array}{l}\text { Solid } 1 \text {-in. -diameter } \mathrm{UO}_{2} \text { sphere } \\
\text { surrounded by } 1 / 4 \text {-in. graphite } \\
\text { cladding }\end{array}$ & 1.2 & 1040 & 935 & 905 \\
\hline 11 & Battelle & Ditto & 1.4 & 1225 & 1100 & 1065 \\
\hline E-16 & Sylvania Corning & $\begin{array}{l}\text { Impregnated specimen with } \mathrm{UO}_{2} \\
\text { uni formly distributed }\end{array}$ & 1.6 & 1370 & 1220 & 1180 \\
\hline$E-13$ & Sylvania Coming & Ditto & 1.8 & 1355 & 1205 & 1170 \\
\hline
\end{tabular}

(a) The specimens are located in the capsule in the order listed. The flux peaks (about $3.6 \times 10^{13}$ nv) about midway between Specimens 11 and 12 and drops off toward the ends. The Battelle-fabricated specimens were located in the peak flux zone because their relatively concentrated fuel loading was expected to result in a relatively high perturbation.

(b) Heat generations are estimated from temperature data and heat-transfer considerations. The reference thermocouples are located in graphite blocks in the equatorial

planes. These blocks serve as the specimen housings; each specimen is actually cushioned in a graphite-powder annulus 30 mils thick.

(c) These temperatures were estimated as follows:

Nominal - Using the reference temperature data indicated in (b) and a powder themal conductivity based on an average packing density.

Minimum - As above, except using a powder conductivity based on a maximum packing density.

Maximum - Using temperature data obtained from two thermocouples, the tips of which are inserted in $1 / 16-1 \mathrm{n}$. -deep holes drilled into the surface of NC-86 and relating the temperatures indicated here to other specimens according to heat generation. 
$J-1$

\section{J. CORROSION PROBLEMS ASSOCIATED WITH THE RECOVERY OF SPENT REACTOR FUEL ELEMENTS}

C. L. Peterson, P. D. Miller, O.M. Stewart, W. C. Baytos, J. D. Jackson, T. E. Snoddy, and F. W. Fink

Materials of construction for use in the various proposed processes for the recovexy of spent reactor fuel elements are being evaluated.

Titanium remains the material of choice for all conditions studied in the Darex process and there has been no evidence of serious attack.

A satisfactory heat treatment has not been found, as yet, which will improve the corrosion resistance of Carpenter $20 \mathrm{Cb}$ to fufüric acid solutions, but encouraging results have been obtained with heat-treated Ni-o-nel in both the Sulfex and Thorex solutions. Carpenter $20 \mathrm{Cb}, \mathrm{Ni}-\mathrm{O}-\mathrm{nel}$, and Illium 98 are still being considered for the dissolver in this combined process. Several other alloys have been eliminated from further evaluations.

The addition of hydrogen to the Hf sparge inhibits the corrosion of INOR-1 and INOR-8 specimens in the equimolar $\mathrm{NaF}_{\mathrm{F}} \mathrm{Z} \mathrm{F}_{4}$ salt of the fluoride-volatility process but is without effect against the more corrosive conditions found in the $43 \mathrm{NaF}-57 \mathrm{LiF}$ (mole per cent) salt. Whether the more severe corrosion is caused by temperature differences $(650 \mathrm{C}$ in $\mathrm{NaF}-\mathrm{ZrF} 4,700 \mathrm{C}$ in $\mathrm{NaF}-\mathrm{LiF}$ ), different salt compositions, or both has not been determined. Trace quantities of oxygen in the HF sparge did not seem to affect the corrosion of impingement specimens.

\section{The Darex Process}

Uranium can be recovered from fuel elements containing stainless steel as a diluent, or as a cladding, by means of the Darex process. The elements are first dissolved in dilute aqua regia. The chlorides are stripped from the solution with concentrated nitric acid and, following suitable adjustment, the dissolved uranium is recovered by conventional methods of solvent extraction.

\section{Dissolver Studies With Titanium}

The flowing-dissolver experiment, involving the weekly caustic cleaning regimen, was terminated following 2008 hr of exposure. The corrosion rates, as measured by loss in weight of the specimens, are very low. No manifestations of severe corrosion have been revealed by surface inspections, even on titanium specimens which were subjected to daily mechanical abuse. A metallographic study will be conducted with selected specimens containing stressed weldments, crevices, or the intentional scratches. 


$$
J-2
$$

Experiments are now under way with titanium steam tubes exposed in Beginning and Middle Darex solutions and in the initial $2 \mathrm{M} \mathrm{HCl}, 5 \mathrm{M}$ HNO 3 solution. These will be continued for some time before a final inspection by means of metallographic sectioning is made. Outward appearances do not indicate that any serious attack is occurring.

\section{FAT Studies With Titanium}

The final results of corrosion studies of the feed-adjustment system were described in BMI-1294. No further investigations have been conducted on this system.

\section{The Sulfex-Thorex Process}

The evaluation of various metals and alloys for use as a container material for the dissolution step of a proposed Sulfex-Thorex process has continued. In this particular process, stainless-clad fuel elements of thorium or thoria would be dejacketed by dissolution in sulfuric acid. Following this, the thorium or thoria would be dissolved by a solution of $13.0 \mathrm{M} \mathrm{HNO}_{3}, 0.05 \mathrm{M} \mathrm{F}^{-}$, to give a final solution of about $8.5 \mathrm{M} \mathrm{HNO} 3$, $0.05 \mathrm{M} \mathrm{F}^{-}$, and 1.0 M Th(NO $\mathrm{NO}_{3}$. Experience has already pointed out that the addition of $0.2 \mathrm{M} \mathrm{Al}^{+3}$ to the Thorex solutions will aid in preventing excessive corrosion of several materials, and such an addition will probably be used in operation of this process.

\section{Experiments With Carpenter $20 \mathrm{Cb}$}

Exposure to boiling $6 \mathrm{M} \mathrm{H}_{2} \mathrm{SO}_{4}$ of the specimens heat treated at 1550, 1650, 1750, and $1850 \mathrm{~F}$ (see BMI-1294) was continued for a total of $192 \mathrm{hr}$. In most cases, the corrosion rates increased substantially over those measured at $96 \mathrm{hr}$. Severe pitting continued to occur, especially on those treated at the lower temperatures. The only cracking seen was observed after the 192-hr exposure around figures stamped in the specimens at the time of the 96-hr inspection and, therefore, not subjected to annealing.

It was thought that possibly the severe pitting and high-corrosion rates might be related to the composition or structure of the specimens at or near their surfaces. This was disproved, however, when two specimens, surface finished to expose clean surfaces below the depth of any previous pitting, showed high-corrosion rates and developed pitting, as before, upon exposure to boiling $6 \mathrm{M} \mathrm{H}_{2} \mathrm{SO}_{4}$.

A limited metallographic study of the exposed heat-treated Carpenter $20 \mathrm{Cb}$ specimens is planned. No further evaluation studies in acid solutions are planned until representatives of the manufacturer have had an opportunity to examine the results with this alloy and suggest methods for improvement of its corrosion resistance to the Sulfex-Thorex solutions. 
$J-3$

Experiments With Ni=0-nel

Specimens of stabilized Ni-o-nel (titanium-to-carbon ratio of 27 to 1 ) were given a heat treatment (1850 for $30 \mathrm{~min}$, air quenched) and machined to provide clean, smooth surfaces. These were exposed to boiling Initial and Final Thorex solutions containing $0.2 \mathrm{MAl}+3$ with examinations after $24,96,192,288$, and $500 \mathrm{hr}$. The corrosion rates decreased steadily in both solutions during the first $192 \mathrm{hr}$ and then leveled out to constant values of 0.67 and $0.38 \mathrm{mil}$ per month in the Initial and Final Thorex solutions, respectively. Metallographic examination of specimens exposed to Initial Thorex solutions revealed a slight amount of selective attack adjacent to the weldment where intergranular penetrations of about $5 \mathrm{mils}$ had occurred in isolated spots. While this is a substantial penetration, it is cextainly an improvement over the results with the as-welded material. No selective attack was observed on specimens exposed to the Final Thorex solution.

Presently, studies are under way in which the corrosion rates of heat-treated $\mathrm{Ni}-0$-nel specimens exposed to the vapors above refluxing $6 \mathrm{M} \mathrm{H}_{2} \mathrm{SO}_{4}$ will be compared with rates for specimens exposed above similar solutions in which dissolution of stainless steel is occurring. This latter condition has been observed to be significantly more corrosive than the formex in studies conducted with specimens of Carpenter $20 \mathrm{Cb}$.

The effects on the corrosion resistance of stabilized Ni-o-nel produced by heat treatments at $1650 \mathrm{~F}$ followed by air quenching, as suggested by the manufacturer, will be studied. Welded specimens will be heat trealed 1 and $24 \mathrm{hr}$. Material will also be heat treated 2 and $10 \mathrm{hr}$ prior to welding. All specimens will be evaluated by exposure to boiling Initial Thorex solutions containing $0.2 \mathrm{M} \mathrm{Al}^{+3}$ additions.

\section{Scouting Experiments With Other Metals}

Further exposure of Illium 98 has shown that this alloy is subject to selective attack adjacent to weldments upon exposure to Initial Thorex solutions containing aluminum. Incipient pitting was observed from exposure to the sulfuric acid solutions. This material is still considered as a candidate, but further studies with Illium 98 will be suspended until the possibility of remedial heat treatments has been explored.

Scouting experiments were conducted with specimens of Haynes 21 , Haynes 25 , Type S-590, Type S-816, and Inconel 700. Only the boiling $6 \mathrm{M} \mathrm{H}_{2} \mathrm{SO}_{4}$ and aluminumcontaining Initial Thorex solutions were used for evaluation, as these now appear to present the most severe conditions to which candidate materials of construction will be subjected. All of these alloys were excessively attacked by the boiling $6 \mathrm{M} \mathrm{H}_{2} \mathrm{SO}_{4}$ liquid and, in the Initial Thorex solution, only the corrosion rate of Haynes 21 was encouraging. None of these alloys are presently being considered further for use in a combined Sulfex-Thorex process. 
The Fluoride-Volatility Process

Fuel elements containing zirconium as a diluent or cladding can be recovered by a fluoride-volatility process. The first step consists of hydrofluorination of the elements in a bath of molten fluoride salts using a HF sparge. Various materials are being evaluated for use in the construction of this hydrofluorinator.

In BMI-1294, it was shown that the addition of 2.4 per cent hydrogen to the $H F$ sparge inhibited the corrosive attack on specimens of INOR-1 and INOR-8 in the equimolar $\mathrm{NaF}-\mathrm{ZrF}_{4}$ salt at $650 \mathrm{C}$. Studies in the same salt composition have now been completed in which the effect of the addition of $20 \mathrm{ppm}$ of oxygen to the HF was measured. It was found that the corrosion on the impingement specimen was about the same as was noted with HF alone.

Experiments have also been completed on the study of the effect of hydrogen additions on the corrosion in the $43 \mathrm{NaF}-57 \mathrm{LiF}$ (mole per cent) salt at $700 \mathrm{C}$. It was found that severe corrosion occurred in this salt in less than $200 \mathrm{hr}$, regardless of whether hydrogen was or was not added to the HF. Coupon specimens of INOR-8 about 64 mils thick and of INOR-1 about 46 mils thick were severed or almost severed when exposed at the liquid-gas interface position. Hastelloy $W$ tubes with a $35-\mathrm{mil}$ wall thickness were also severed. At this time, it is not known whether the severe corrosion is caused by the high temperature or by the salt composition. Studies aimed at answering this question are under way. 
$\mathrm{K}-1$

K. DEVELOPMENTS FOR SRE, OMRE, AND OMR.

F.A. Rough and J. E. Gates

Work reported in this section is part of the Atomics International research program. The objectives of this research are to develop uranium monocarbide as a fuel for the SRE and to perform postirradiation studies of materials of interest to the SRE, OMRE, and OMR programs.

EVALUATION OF URANIUM MONOCARBIDE AS A REACTOR FUEL

F. A. Rough

The first capsule of uranium monocarbide irradiated to about $970 \mathrm{MWD} / \mathrm{T}$ has been examined with satisfactory results. Some swelling was observed and a few transverse cracks.

It is too early to evaluate UC as a fuel, but the results are not discouraging. Details of the irradiated-specimen examination and other studies are reported below.

Room Temperature-Elastic Modulus and Compressive Strength of Uranium Monoca rbide

J. Melehan and F. A. Rough

As part of the program on UC, a single test to determine the modulus and compressive strength was made. The single test specimen employed in this experiment was ground from cast UC to final dimension of $3 / 8 \mathrm{in}$ in diameter by $1-5 / 8 \mathrm{in}$. in length. Soft aluminum end caps were attached to the specimen to compensate for the unavoidable nonparallelism of the end faces which would otherwise result in unequal stress distribution and end crumbling. Two SR -4 strain gages were diametrically located for measurement of compressive strain. Loads were applied through ball-and-socket-type platens, and several preliminary low-load applications were carried out to seat the specimens in the end caps and for final adjustment of specimen position for axial loading.

The specimen was subjected to three loading cycles where maximum stresses of $5,450,27,250$, and 54,500 psi were attained; the latter stress was the rupture strength. The strain data from the two gages showed increasing divergence with increasing stress; therefore, it is apparent that despite preliminary efforts, nonaxial loading had occurred. The modulus value averaged from the three determinations is $31.5 \times 10^{6} \mathrm{psi}$. The deformation remained in the elastic range with total strain at rupture of 0.17 per cent.

This concludes this single test. 
$\mathbf{K}-2$

Irradiation of Uranium Monocarbide

R. B. Price and W. H. Goldthwaite

Capsule BMI-23-2, containing uranium-5.0 w/o carbon specimens, is being irradiated in MTR Position A-38-NE in a thermal-neutron flux of about $1 \times 10^{14} \mathrm{nv}$. The capsule was inserted during Cycle 110 shutdown, and probably will be discharged during Cycle 114 shutdown, after a four-cycle irradiation. Capsule BMI-23-3 (uranium-5.0 w/o carbon) is at the MTR awaiting insertion, possibly during Cycle 113 shutdown. Capsule BMI-23-4 (uranium-5.0 w/o carbon) is being loaded and will be shipped to the MTR next month; it will arrive in time for preinsertion tests for Cycle 114 shutdown. Specimens are available and ready for loading in Capsules BMI-23-5 (uranium-4. $8 \mathrm{w} / \mathrm{o}$ carbon) and BMI-23-6 (uranium-4.6 w/o carbon). These loadings will be in progress next month.

\section{Postirradiation Examination of Uranium Monocarbide}

S. Alfant, G. Lamale, A. W. Hare, and F. A. Rough

The program to study the effects of irradiation on uranium monocarbide is being continued. MTR Capsule BMI-23-1, containing uranium-5.0 w/o carbon specimens, has been discharged from the test reactor and is in the process of being examined. Preliminary examinations indicated that the specimens in this capsule, AI- 2 and AI- 3 , contained a few transverse cracks.

Fission-gas analysis was completed on Capsule BMI-23-1 by puncturing the capsule and allowing the fission gas to diffuse into two $92-\mathrm{cm}^{3}$ vials. The fission gas was then compressed into three $2-\mathrm{cm}^{3}$ vials so that a more accurate gamma photon count could be taken. The results of the analysis are given in Table $\mathrm{K}-1$.

The calculated theoretical total fission gas released, based on a 0.1 total a/o burnup, would be $3.2 \mathrm{~cm}^{3}$. A comparison of the results obtained below, and the theoretical total gas released, indicate a variation, which may be caused by the phenomenon of "recoil".

TABLE K 1 1. KRYPTON $\infty 5$ ANALYSES

\begin{tabular}{lccc}
\hline & & Krypton-85 Analysis & $\begin{array}{c}\text { Amount Formed, } \\
10^{-5} \mathrm{~cm}^{3}\end{array}$ \\
\cline { 2 - 4 } & $\begin{array}{c}\text { Gamma Photons, } 10^{3} \text { counts } \\
\text { per min }\end{array}$ & $10^{14}$ atoms & $2.35 \times 10^{-5} \mathrm{~cm}^{3}$ \\
$38 \mathrm{~L} 4$ & $7.27 \times 10^{3}$ & $6.32 \times 10^{14}$ & $2.35 \times 10^{-5} \mathrm{~cm}^{3}$ \\
$40 \mathrm{~L} 4$ & $7.49 \times 10^{3}$ & $6.32 \times 10^{14}$ & $2.32 \times 10^{-5} \mathrm{~cm}^{3}$ \\
$42 \mathrm{~L} 16$ & $6.59 \times 10^{3}$ & $6.25 \times 10^{14}$ & $2.32 \times 10^{-5} \mathrm{~cm}^{3}$ \\
$43 \mathrm{~L} 16$ & $6.96 \times 10^{3}$ & $6.25 \times 10^{14}$ & $2.35 \times 10^{-55} \mathrm{~cm}^{3}$ \\
$45 \mathrm{~L} 4$ & $7.87 \times 10^{3}$ & $6.32 \times 10^{14}$ & \\
\hline
\end{tabular}


$\mathrm{K}-3$

Capsule BMI-23-1 was irradiated $970 \mathrm{MWD}$ at 39.8 megawatts in a flux of approximately $8 \pm 0.2 \times 10^{13} \mathrm{nv}$ thermal. Extreme measured core surface temperatures, respectively, were about 1600 and 1000 For Specimen AI-3. Because Specimen AI- 2 was positioned below AI-3, it operated at a temperature and flux below those quoted above. Prior to irradiation, dosimeter wire was wound circumferentially around the specimens, and lengthwise outside the stainless steel capsule. The wires wound around the specimens were removed in three sections measuring approximately $2-1 / 2 ; 1-1 / 4$; and $2-1 / 2$ in., all to be used in the neutron dosimetry analysis. Included in this analysis were two specimens of dosimeter wire taken from the outside surface of the capsule. Results of this analysis are given in Table $\mathbb{K}-2$, but burnups based on the dosimetry have not yet been calculated.

TABLE K-2, DOSIMETRY FOR CAPSULE BMI-23-1

\begin{tabular}{|c|c|c|c|c|c|}
\hline \multicolumn{3}{|c|}{ Dosimeter Wire } & \multirow{2}{*}{$\begin{array}{l}\text { Irradiation } \\
\text { Time, days } \\
\end{array}$} & \multirow{2}{*}{$\begin{array}{c}\text { Decay Time, } \\
\text { days }\end{array}$} & \multirow{2}{*}{$\begin{array}{c}\text { Thermal - Neutron Flux, } \\
1013 \mathrm{nV}\end{array}$} \\
\hline Designation & Location & Composition & & & \\
\hline $2 \mathrm{~A}$ & Specimen $\nrightarrow$ top & $\mathrm{Ti}=\mathrm{Co}$ & 24.35 & 45 & 4.32 \\
\hline $2 \mathrm{~B}$ & Specimen-middle & $T i=C O$ & 24.35 & 45 & 3.68 \\
\hline $2 \mathrm{C}$ & Specimen bottom & $\mathrm{Ti} \propto \mathrm{CO}$ & 2435 & 45 & 3.45 \\
\hline 3 & Capsulemoutside wall & $A 1 \propto C 0$ & 24,35 & 45 & 6.02 \\
\hline 4 & Capsule outside wall & $\mathrm{Al}=\mathrm{CO}$ & 24,35 & 45 & 3.65 \\
\hline
\end{tabular}

Because of the few transverse fractures occurring in the specimens, successful measurements of length were not completed. However, measurements of diameter and density were completed on Specimens AI-2 and AI-3. These results, when compared with the preirradiation measurements, indicated that Specimen AI-2 showed a gain of 0.4 per cent in diameter and a loss of $0.09 \mathrm{~g}$ per $\mathrm{cm}^{3}$ in density after irradiation, and AI- 3 showed a 0.3 per cent gain in diameter and a loss of $0.04 \mathrm{~g}$ per $\mathrm{cm}^{3}$ in density.

Stereomacrographs were completed on Capsule BMI-23-1 with a survey of all specimens taken at $4 \mathrm{X}$ and $6 \mathrm{X}$ magnification; an increase in magnification to $16 \mathrm{X}$ was used for studies of defects or other items of obvious interest. Metallography and radiochemical analyses of burnup have been started, and the results should be forthcoming in the very near future.

\section{Fission-Product Release From Irradiated Uranium Monocarbide}

R. Lieberman, D. N. Sunderman, and M. Pobereskin

The objective of this work is to determine the amount of fission product, xenon133, released from uranium carbide as a function of time and temperature of postixradiation heating.

Gas-release studies were continued utilizing uranium carbide of near-theoretical density. The specimen had received an effective radiation exposure of $5.76 \times 10^{13} \mathrm{nvt}$ 
$\mathrm{K}-4$

as determined by cobalt dosimetry, corrected for flux attenuation by the specimen. The irradiated uranium carbide specimen was placed in a closed, evacuated system and heated at several temperatures up to $1800 \mathrm{~F}$. Samples of gas were collected by absorption in charcoal traps which had been evacuated and cooled with liquid nitrogen. The individual traps were isolated and xenon- 133 concentrations were measured by means of gamma-ray spectrometry.

Upon cooling it was noted that the cylindrical specimen of uranium carbide had fragmented. A sample of gas was collected after the specimen (I-2) had cooled to room temperature. The broken specimen was reheated to $1700 \mathrm{~F}$ for $24 \mathrm{hr}$ and a final gas sample ( $\mathrm{J}-2)$ was collecred and measured.

Considering that fracturing and some fragmentation occurred in the specimen, the indicated fission-gas retention was excellent.

Results of the gas analysis are shown in Table $\mathrm{K}-3$.

TABLE K $\sim 3$. FISSION $-G A S$ RELEASE FROM URANIUM CARBDE AS A FUNCTION OF TIME AND TEMPERATURE OF POSTIRRADIATION HEAT TREATMENT

\begin{tabular}{|c|c|c|c|}
\hline Gas Sample & $\begin{array}{l}\text { Temperature, } \\
\text { F }\end{array}$ & $\begin{array}{l}\text { Total Time at } \\
\text { Temperature, hr }\end{array}$ & $\begin{array}{c}\text { Fraction of Total Present } \\
\text { Xenon } 133 \text { Found }\end{array}$ \\
\hline$A=2$ & 1500 & 24 & .0001 \\
\hline$B=2$ & 1000 & 24 & .000061 \\
\hline$C=2$ & 1700 & 24 & .000048 \\
\hline$D=2$ & 1700 & 96 & .000178 \\
\hline$E \propto 2$ & 1700 & 120 & .000178 \\
\hline$F-2$ & 1700 & 148 & .000178 \\
\hline$G=2$ & 1800 & 24 & .000079 \\
\hline $\mathrm{H}-2$ & 1800 & 48 & .000079 \\
\hline$I \infty 2$ & 75 & 72 & Trace \\
\hline$J-2$ & 1700 & 24 & Trace \\
\hline
\end{tabular}

(a) Cumulative value for time at temperature.

\section{POSTIRRADIATION STUDIES OF SRE, OMRE, AND OMR FUEL MATERIALS}

J. E. Gates

Radiochemical burnup analyses of ir radiated thorium-11 w/o uranium specimens from Capsule Trains NAA-15-6 and NAA-15-7 are approaching completion. Techniques are being developed for metallographic examination of these specimens.

Specimens for radiochemical burnup analyses and metallographic examination have been cut from the $\mathrm{UO}_{2}$ fuel pins irradiated in Capsules NAA-28-1 and NAA-29-1. 
$K-5$

The examination of Fuel Element OMRE-3 is approaching completion. Tar sampling has been completed and fuel-plate thickness measurements and radiochemical burnup analyses are in progress. Gamma-activity scans and metallographic examination of selected fuel plates remain to be performed.

Examination of the twelve corrosion specimens irradiated in dummy Fuel Element OMR- 1 is completed. The exrmination of $18 \mathrm{U}$-bend specimens and analysis of data obtained from the 12 tensile specimens are in progress. Equipment is being prepared for testing 12 impact specimens.

SRE Fuel Material

G. E. Lamale, J.H. Saling, and J.E. Gates

Thorium-Uranium Specimens

The evaluation of data obtained from the examination of the thorium- $11 \mathrm{w} / \mathrm{o}$ uranium specimens from Capsule Trains NAA-15-6 and NAA-15-7 is being continued. Radiochemical burnup analyses are in progress on samples cut from specimens irradiated in both capsule trains. Preliminary results indicate that specimens irradiated in Capsule Train NAA-15-6 experienced a burnup of 1.1 to 1.4 total a/o.

Metallography of selected specimens from both capsule trains has been initiated. Difficulties have been encountered in producing a satisfactory etch on an unirradiated control specimen. However, a cathodic etching procedure is now producing satisfactory results on the control specimen. This technique will have to be adopted for use in the hot cell and may delay completion of the metallographic examination of the irradiated specimens.

\section{Uranium Dioxide Specimens}

The postirradiation evaluation of uranium dioxide specimens from Capsules NAA-28-1 and NAA-29-1 is continuing. The fuel pins from Capsules NAA-28-1 and NAA-29- I have been sectioned by abrasive wheel under water for metallographic examination and radiochemical burnup analysis. The $\mathrm{UO}_{2}$ was badly cracked and care was required to keep the pieces from falling out of the stainless steel sheath. It will be necessary to press a binder material into the sections cut for metallography to hold the fractured pellets together during mounting and polishing. Equipment will be constructed for this purpose. The metallographic examination, dissolution of the three burnup samples, and the radiochemical burnup analysis of specimens taken from Capsule NAA-29-1 will be initiated next month. 


$$
\mathrm{K}-6
$$

OMRE Fuel Elements

R. J. Burian, D. K. Dieterly, D. N. Sunderman, and J. E. Gates

The postirradiation examination of Fuel Element OMRE-3 is approaching comple: tion. A sample of the carbonaceous tar layer has been collected and the plate thickness measurements are in progress. The remaining examinations include the radiochemical burnup analysis of slugs punched from three fuel plates, and a gamma-activity scan of these plates. All phases should be completed next month. A topical report covering the program is being prepared.

OMR Fuel and Structural Materials

R. J. Burian and J,E. Gates

The postirradiation examination of the structural materials irradiated in dummy Fuel Element OMR-1 is in progress. The examination of the six welded and the six unwelded corrosion specimens has been completed. The testing phase of the tensilespecimen examination is completed and an analys is of the data is in progress. The examination of the $U$-bend specimens is approaching completion. Testing of impact specimens will begin as soon as the equipment is available, probably next month.

Data obtained from the unwelded ferrous corrosion specimens indicated that these specimens had experienced less than a 0.2 per cent weight change during ir radiation. A much greater weight loss was measured for the aluminum and magnesium specimens. However, subsequent tests on unirradiated aluminum and magnesium control specimens revealed that a large part of the weight loss could be attributed to a chemical reaction between the specimens and the cleaning solution used to loosen the carbonaceous tar layer. The cleaning solution had been satisfactorily tested on other unirradiated aluminum specimens prior to its use.

The welded corrosion specimens appeared to be in good condition. No pitting or other surface defects were noted. Stereomacrographs were taken. Weight measurements were not scheduled as part of the examination of the welded corrosion specimens. 


\section{$L_{-1}-1$ \\ L. TANTALUM AND TANTALUM-ALLOY STUDIES}

J. H. Stang

This section covers two research investigations dealing with materials for plutonium-alloy containment in the Los Alamos molten-plutonium reactors (LAMPRE). The first investigation is currently concerned with the development of tantalum-base containment materials, while the second is a study of irradiation damage in tantalum, the material to be used in LAMPRE I now under construction at Los Alamos. Each of these programs is in the preliminary stage and the activity last month was confined to laying groundwork necessary to their research during the coming months.

\section{Development of Container Materials for LAMPRE Applications}

D. C. Drennen, M. E。 Langston, C.J. Slunder, and $J . G$. Dunleavy

The preparation of an initial series of tantalum and tantalum-tungsten alloys for plutonium-alloy compatibility evaluation at Los Alamos is in progress. Button specimens (weighing $200 \mathrm{~g}$ ) of unalloyed tantalum and of tantalum plus 1.5, 3.0, and 6.0 w/o tungsten are being produced by arc melting. This melting technique utilizes a copper mold, tungsten electrode, and a helium atmosphere. An evaluation of the soundness, homogeneity and purity of the cast specimens is to be obtained by hardness measurements, radiographic inspection, metallographic examination, and chemical analysis.

The technique for the processing of buttons to strip specimens for property evaluations will include machining of the cast surfaces if necessary, degreasing, etching in $\mathrm{H}_{2} \mathrm{SO}_{4}-\mathrm{HNO}_{3}-\mathrm{HF}$ solution, cold rolling to a thickness of $30 \mathrm{mils}$ using Palmo Shield lubricant and intermediate etchings, and final degreasing and etching. Rolling studies will follow and hardness measurements will be made at various percentages of cold reduction to obtain an indication of the degree of work hardening. $X$-ray fluorescence tests and chemical analyses will be made on the finished strip to determine the extent of contamination resulting from processing.

\section{Irradiation Damage of Tantalum}

E. J. Jablonowski, F. R. Shober, F. A. Rough, and $R$. Fickerson

The objective of this study is to determine the effect of neutron ixradiation on the mechanical properties of tantalum. Exposure to the LAMPRE flux will result in two types of structural modifications to the tantalum; these are: (1) a conversion of tantalum to tungsten, and (2) the formation of vacancy-inter stitial combinations associated with atom displacements. A comparison of the tensile properties of irradiated tantalum and 


$$
\mathrm{L}-2
$$

unirradiated tantalum and tantalum-tungsten alloys will be made in an attempt to separate the effect of alloying (transmutation) from the effect of atom displacement (fastneutron damage) produced by irradiation.

The integrated thermal-neutron flux needed to transmute $1.5 \mathrm{w} / 0$ and $3.0 \mathrm{w} / \mathrm{o}$ tantalum to tungsten has been calculated and found to be $7 \times 10^{20}$ nvt and $14 \times 10^{20} \mathrm{nvt}$, respectively. Twelve sheet tensile specimens of tantalum will be exposed. This will require two capsules and, currently, preliminary capsule designs are being prepared. One of the se designs involves a cylindrical aluminum capsule in which the tantalum specimens are surrounded by a helium atmosphere. In such a capsule, the specimens would reside at a temperature of approximately $1000 \mathrm{~F}^{\circ}$ because of the combination of high gamma heating incurred in available lattice positions of the ETR or MTR and the low thermal conductivity of the helium. In an alternate capsule design now being appraised, NaK is substituted for the helium and stainless steel is substituted for the aluminum; the specimen temperature calculated for this situation is not significantly above that of the process water $(120 \mathrm{~F})$.

Thermal and fast-neutron flux available in the ETR and MTR indicates that transmutation of 1.5 and $3 \mathrm{w} / \mathrm{o}$ tantalum to tungsten will occur at flux levels which may not induce a notable amount of fast-neutron damage. In view of this, consideration is being given to the construction of a third irradiation capsule to contain tantalum specimens shielded from thermal neutrons by a cadmium linex (thus, exposed to fast-neutron flux only). 
$\mathrm{M}-1$

\section{DEVELOPMENTAL STUDIES FOR THE PWR}

R. W. Dayton

Eight designs of flow baffles and swirl vanes were studied in the PWR model. The configuration having the best performance is being designed in a form suitable for the prototype, and a model of this design will then be tested.

Pressure-bonding studies are being continued to study the best conditions for preparing oxide plates using builtup frames for separating compartments. Unjacketed specimens, with abraded cover plates and pickled separators, have possessed good bonds after bonding at $1550 \mathrm{~F}$, followed by an $1850 \mathrm{~F}$ beta treatment.

\section{Reactor Flow Studies}

L. J. Flanigan and H. R. Hazard

Flow studies using air in a quarter-scale model of the PWR are being conducted to determine the effects of lower-plenum geometry on mixing and on flow distribution in Core 2. Previously reported work includes exploratory studies of upper-plenum mixing with Core 1 configuration and studies of mixing in the lower and upper plenums with the 7.5-ft core design.

Last month, eight lower-plenum configurations were studied for the 7.5-ft Core 2 design. These included various shroud-ring designs which reduced the flow area of the $30-\mathrm{deg}$ swirl vanes used both with and without deflector vanes at the inlets.

The lower-plenum configuration, providing the optimum combination of mixing and pressure drop, consisted of a flow baffle with 312 holes $11 / 16$ in. in diameter, 30-deg swirl vanes attached to the flow baffle with a 3/4-in. - wide shroud ring attached to the upper end of the vanes, and 45-deg deflector vanes positioned 1 in. from the edge of the inlets. Drawings of this final configuration were submitted for design of a similar configuration suitable for incorporation into the prototype. A quarter-scale model of the prototype design will then be installed in the air-flow model to verify its performance.

Pressure Bonding of Zircaloy-2-Clad Fuel Elements Containing Compartmented Oxide Fuel Plates

S. J. Paprocki, E. S. Hodge, D. C. Carmichael, and $\mathbb{P}$. J. Gripshover

A flat-plate Zircaloy-2-clad fuel element containing compartmented uranium dioxide fuel is being considered for PWR Core 2. An investigation is being conducted to study the preparation of these elements by gas-pressure bonding. In the technique currently being investigated, the Zircaloy- 2 receptacle plates to receive the cores are 
$\mathrm{M}-2$

assembled from strip components, and the receptacle is fusion welded to the cover plates at the edges prior to bonding to form a gastight assembly.

Eight small specimens have been pressure bonded under various conditions in order to further evaluate bonding of piece-component Zircaloy-2 frames and to investigate the surface-preparation requirements for pressure bonding at 1550 and 1750 F to achieve consistent bonding. The se specimens were prepared using piece-component frames and were edge welded. Each specimen contained four uranium dioxide cores separated by $0.100-\mathrm{in}$ - -wide Zircaloy-2 ribs. The uranium dioxide cores were coated with a thin layer of graphite applied by spray coating with Aquadag, a suspension of graphite in water, to attempt to minimize core-cladding reaction. Surface preparations studied in this series involved all abraded components, all pickled components, and abraded cover plates in contact with pickled receptacle-plate components. The pickling solution used for the specimens was 5 per cent $\mathrm{HF}^{-}-45$ per cent $\mathrm{HNO}_{3}-50$ per cent alcohol (by volume). The cover plates for all of the specimens were completely edge welded to the receptacle plate in a helium atmosphere except for a small opening in one end of the specimen. The residual helium from the welding operation was evacuated through this opening and the final closure was made in air. Pressure bonding was performed at 10,000 psi for $4 \mathrm{hr}$ at a temperature of 1550 or $1750 \mathrm{~F}$. After bonding, some of the specimens were heat treated in a salt bath at $1850 \mathrm{~F}$ for $5 \mathrm{~min}$, followed by quenching in a stream of helium.

Evaluation of the specimens was based on intercompartmental leak tests, burst tests, defected-compartment corrosion tests, radiographic study, and metallographic examination. The results obtained for these specimens were encouraging. Intercompartmental leakage, as revealed by leak tests or burst tests, did not occur in any of the eight specimens. Therefore, it appears that the piece components forming the receptacle plate can be bonded to obtain good intercompartmental integrity with pickled or abraded surfaces at 1550 and $1750 \mathrm{~F}$. For these specimens, the longitudinal rib was a single piece and the short cross ribs had to be bonded to the longitudinal rib and the side sections of the receptacle to form the core-insert compartments.

The cladding of specimens bonded at 1550 and $1750 \mathrm{~F}$ and with and without the $1850 \mathrm{~F}$ heat treatment appeared ductile during burst testing; however, increased ductility was observed for all specimens which had received the additional $1850 \mathrm{~F}$ heat treatment.

Results of corrosion tests on defected compartments are satisfactory after short periods of testing for two of the specimens that were not sectioned. Portions of the remaining specimens have been placed on test in $680 \mathrm{~F}$ water and have shown no significant growth from corrosion attack after 3 or 7 days. However, exposure time is too short at present for the results to have much significance. The corrosion resistance of the Zircaloy-2 cladding of these specimens appears satisfactory. Radiographic examination revealed no uranium dioxide particles in the component interfaces either after final as sembly or after pressure bonding.

Metallographic examination showed that bond lines were uncontaminated. Grain growth was incomplete as bonded, but satisfactory after the $1850 \mathrm{~F}$ heat treatment. Specimens in which all components were belt abraded were pressure bonded at $1550 \mathrm{~F}$ and examined as bonded and as bonded and heat treated. These specimens exhibited good bonds at the interface of the piece-frame components and at the interface of the frame components and the cover plates. Good results were also obtained by bonding 
$\mathrm{M}-3$

pickled frame components to abraded cover plates at $1750 \mathrm{~F}$ followed by a heat treatment at $1850 \mathrm{~F}$. The bonds obtained at the interfaces of the pickled surfaces of the frame components were also satisfactory. A specimen prepared under similar conditions which was not heat treated at $1850 \mathrm{~F}$ exhibited a partial lack of grain growth across the bond interface.

An additional specimen with abraded cover plates and pickled receptacle-plate components was bonded at $1550 \mathrm{~F}$ and subjected to the $1850 \mathrm{~F}$ heat treatment. The results of this specimen were encouraging but were not conclusive because of helium entrapped in the specimen. Consequently, it is not yet certain if components prepared with abraded cladding and picleled receptacle components can be bonded as well at $1550 \mathrm{~F}$ followed by heat treatment as they have been at 1750 followed by the heat treatment.

Several specimens bonded at 1750 F with pickled cover plates and pickled receptacle components were not given a subsequent beta treatment. A lack of grain growth across the bond interface was observed in some areas of these specimens; however, an additional heat treatment at $1850 \mathrm{~F}$ would probably have improved bonding in such specimens by promoting additional grain growth across the interface. All of the specimens in this series exhibited, in varying amounts, some very small spherical voids along the bond interface. These voids are believed due to entrapped helium from the edge-welding operation, since one specimen known to contain entrapped helium showed an increased number of such voids. These specimens had been subjected to evacuation prior to finall sealing in air; however, all of the helium apparently had not been removed. Subsequent specimens are being evacuated for a longer time prior to final closure.

The amount of core-cladding reaction which occurred in the various specimens was also examined metallographically. No uranium-zirconium reaction zones were observed in the specimens, but zones of oxygen-rich Zircaloy-2 were present in areas around the cores in some of the specimens. These zones were most prevalent at the corners and edges of cores, and in the specimens bonded at $1750 \mathrm{~F}$. The average density of the graphite coating on these cores was approximately $1.7 \mathrm{mg}$ per in. In subsequent specimens thicker coatings will be investigated in an attempt to eliminate or minimize the zones of oxygen-rich Zircaloy-2. Additional coating thickness along the core edges will definitely be necessary and may be obtained by modifying the spraying technique used to coat the cores. Ertended corrosion tests will be necessary to determine the extent of the core-cladding reaction problem for all specimens, including those bonded at $1750 \mathrm{~F}$.

Components have been machined for 14 large-scale elements which will be prepared using piece-component receptacles. All of these specimens will be edge welded. These elements are approximately $1 / 8$ by $4-5 / 8$ by $15 \mathrm{in}$. and contain three groups of 11 compartments $1 / 4$ in. wide across the transverse direction. Two groups of compartments are $3 \mathrm{in.}$ long and one group is $6 \mathrm{in.}$ long in the longitudinal direction of the element. The Zircaloy -2 ribs forming the compartments are all $0.040 \mathrm{in}$. wide, and the uranium dioxide cores and receptacle-plate components are $0.100 \mathrm{in}$. thick. The initial elements in this series will be bonded at 1550 and 1750 F at 10,000 psi for $4 \mathrm{hr}$ and heat treated in a salt bath at $1850 \mathrm{~F}$ for $5 \mathrm{~min}$. Ir radiation specimens are also being prepared for long-time irradiation tests. Six elements have been pressure bonded at $1550 \mathrm{~F}$ and heat treated using one-piece receptacle plates which were edge welded to the cover plates prior to bonding. Three of these elements were machined from normal Zircaloy -2 and three were machined from nickel-free Zircaloy- 2 in which iron had been 


$$
\mathrm{M}-4
$$

substituted for the nickel that is normally present. Six additional irradiation specimens have been prepared under the same conditions using piece-component receptacles and normal Zircaloy-2. 
$\mathbb{N}-1$

N. DEVELOPMENTS FOR THE MGCR

W. H. Goldthwaite

Investigation of the Effect of Irradiation on Clad Graphite

Specimens in a $\mathrm{CO}_{2}$ Environment

A program to investigate the compatibility of graphite and $\mathrm{CO}_{2}$ with Types 310 and 446 stainless steels and Inconel under conditions similar to proposed Maritime Gas-Cooled Reactor operation is in progress. Small specimens of graphite, clad with the se materials, were irradiated in a capsule environment of $\mathrm{CO}_{2}$ at 1000 psi at 1300 to $1500 \mathrm{~F}$ for 5 weeks in the BRR. Postirradiation examination of the specimens is under way.

Measurements of Density, Weight, and Dimensions

J. D. Bray and J. E. Gates

Measurements of the specimens taken before and after irradiation are presented in Table $\mathrm{N}-1$.

TABLEN-1. SPECIMENS, DIMENSIONS, WEIGHTS, AND DENSITIES

\begin{tabular}{|c|c|c|c|c|c|c|c|}
\hline & $\begin{array}{l}\text { Specimen: } \\
\text { Cladding: }\end{array}$ & $\begin{array}{c}\text { A-1 } \\
310 \text { Stainless } \\
\end{array}$ & $\begin{array}{c}\text { A-2 } \\
310 \text { Stainless } \\
\end{array}$ & $\begin{array}{c}F-1 \\
446 \text { Stainless } \\
\end{array}$ & $\begin{array}{c}\leftarrow-3 \\
446 \text { Stainless } \\
\end{array}$ & $\begin{array}{c}\text { L-2 } \\
\text { Inconel } \\
\end{array}$ & $\begin{array}{c}\mathrm{L}-7 \\
\text { Inconel } \\
\end{array}$ \\
\hline \multicolumn{8}{|c|}{ Preirradiation Data } \\
\hline Weight, $g$ & & 7.2664 & 7.1885 & 7.1975 & 6.9226 & 8.2106 & 8.1302 \\
\hline Length, in. & & 0.7156 & 0.7061 & 0.7028 & 0.7044 & 0.7094 & 0.7320 \\
\hline Diameter, in. & & 0.4481 & 0.4475 & 0.4408 & 0.4412 & 0.4401 & 0.4400 \\
\hline Density, g per $\mathrm{cm}^{3}$ & & 4.39 & 4.39 & 4.72 & 4.56 & 5.09 & 4.88 \\
\hline \multicolumn{8}{|c|}{ Postirradiation Data } \\
\hline Weight, $g$ & & 7.2699 & 7.1708 & 7.2032 & 6.9238 & 8.2194 & 8.1463 \\
\hline Length $(a)$, in. & & 0.7058 & 0.7004 & 0.7119 & 0.7129 & 0.6999 & 0.7285 \\
\hline Diameter, in. & & 0.4501 & 0.4493 & 0.4482 & 0.4508 & 0.4448 & 0.4423 \\
\hline Density, $g$ per $\mathrm{cm}^{3}$ & & 4.40 & 4.41 & 4.59 & 4.56 & 5.10 & 4.87 \\
\hline
\end{tabular}

(a) The length values are not considered significant because of the design of the specimens. An uneven weld bead at each end of the specinens produced variations between repetitive measurements as great as 20 mils. The postirradiation-length data are given as an average of three measurements. 
$\mathrm{N}-2$

Metallography of Clad Graphite Specimens

W. E. Murr, J. B. Melehan, and $\mathrm{F} . \mathrm{A} \cdot$ Rough

Three specimens have been sectioned for metallographic examination. The specimens were cut longitudinally to expose an end-weld area and approximately onethird of the length of the cladding. The specimens were examined metallographically to determine changes in microstructure at the cladding $-\mathrm{CO}_{2}$ and cladding-graphite interfaces as a result of the 5-week irradiation. When examined in the as-polished condition, no noticeable effect of the $\mathrm{CO}_{2}$ environment upon the microstructures of the three cladding materials was observed except for a very thin oxide film at the gas metal interface. At the cladding-graphite contact, there was evidence of a pronounced interaction of graphite with the cladding materials. Further examination of specimens in both the as-polished and etched conditions will be made to determine if this same effect can be noted in areas where changes in microstructure are less pronounced. On the basis of the microstructures and microhardness measurements, and the results of duplicate out-of-pile experiments, an evaluation of the effect of irradiation on the compatibility of three cladding materials will be made.

RWD/CRT:al1 